BULLETIN Bulletin hispanique

HispaniquE Université Michel de Montaigne Bordeaux

$112-2 \mid 2010$

Varia

\title{
El teatro religioso navideño de la Restauración
}

Continuismo y adaptación de una tradición didáctico-burlesca

\section{Alberto del Campo Tejedor}

\section{(2) OpenEdition}

Journals

Edición electrónica

URL: http://journals.openedition.org/bulletinhispanique/1237

DOI: 10.4000/bulletinhispanique. 1237

ISSN: 1775-3821

Editor

Presses universitaires de Bordeaux

\section{Edición impresa}

Fecha de publicación: 31 diciembre 2010

Paginación: 671-716

ISBN: 978-2-86781-709-0

ISSN: 0007-4640

Referencia electrónica

Alberto del Campo Tejedor, «El teatro religioso navideño de la Restauración », Bulletin hispanique [En línea], 112-2 | 2010, Publicado el 05 enero 2014, consultado el 19 abril 2019. URL : http://

journals.openedition.org/bulletinhispanique/1237 ; DOI : 10.4000/bulletinhispanique.1237 


\title{
El teatro religioso navideño de la Restauración. Continuismo y adaptación de una tradición didáctico-burlesca
}

\author{
Alberto del Campo Tejedor \\ Universidad Pablo de Olavide - Sevilla, España
}

L'étude des textes et des contextes, de la création et de la réception du théâtre religieux de Noël au XIXe siècle, et en particulier des divers genres théatraux, rituels et festifs de la deuxième moitié du siècle - zarzuelas, comédies, pastorales, dialogues dramatiques permet de mettre en évidence la continuité et la recréation des topiques et archétypes du mélange sérieux - comique propre aux siècles antérieurs, comme le personnage du berger niais (pastor bobo) ou les railleries cocasses subies par le méchant. Qu'il soit écrit par des hommes ou des femmes, par des lä̈cs ou des clercs et qu'il soit destiné aux adultes ou aux enfants, ce théatre adapte le prodesse et delectare de Noël à un contexte joyeux et permissif d'où disparaissent, cependant, les licences irréverencieuses et l'ambiguïté des drames religieux de la Renaissance et du Siècle d'Or.

El estudio de los textos y contextos, de la creación y recepción del teatro religioso navideño del siglo XIX, especialmente los diversos géneros teatrales y ritual-festivos de la segunda mitad del siglo -zarzuelas, comedias, pastoradas, diálogos dramáticos-revela la continuidad y recreación de tópicos y arquetipos jocoserios de siglos anteriores como el pastor bobo o el escarnio jocoso del malvado. Ya sea de hombre o mujeres, de laicos o clérigos, destinado a adultos o niños, este teatro adapta la singular tradición de prodesse et delectare navideña a un contexto de alegria y permisividad, en que se han extirpado sin embargo las licencias irreverentes y la ambigüedad de los autos y farsas renacentistas $y$ áureos.

Bulletin Hispanique, Tome 112, n 2 - décembre 2010 - p. 671 à 716. 
The study of the texts and contexts, of the creation and reception of the Christmas religious theatre in the nineteenth century -in particular the diverse theatrical genres, ritual and festive, in the second half of the century: zarzuelas, comedies, pastorals, dramatic dialogues - allows us to put into light the continuity and recreation of topics and archetypes of the serious miscellany - a sort of comic peculiar to earlier centuries, like the stupid shepherd (pastor bobo) or the comical scoffing of the bad guy. Whether written by men or women, laymen or churchmen, meant for adults or children, this theatre is able to fit Christmas prodesse and delectare to a merry and festive context, from which, though, the irreverent liberties disappear, as well as the ambiguity of the Renaissance and Golden Century religious dramas.

Mots-clés : Théâtre religieux de Noël - XIX' siècle - Joie - didactisme - Pastor bobo.

\section{El teAtro de la SEgunda MitAd DEL Siglo XIX}

Se ha afirmado, con razón, que en ningún otro siglo de la historia española se ha producido tanto y tan diverso teatro como en el siglo XIX ${ }^{1}$. Pero también desde la historia de la literatura y la crítica literaria se ha lamentado en numerosos casos la ínfima calidad del teatro, especialmente durante la segunda mitad del siglo XIX, en la que "ni un solo texto ha merecido quedar en el repertorio» ${ }^{2}$. Para el filólogo al uso, el que el público acudiera masivamente a los melodramas de bandidos, comedias costumbristas, zarzuelas, buffos y sainetes, desentendiéndose en gran medida del "teatro con carga literaria» ${ }^{3}$, tragedias o dramas históricos, por ejemplo, solo puede merecer plantos fúnebres: «La etapa que ahora nos ocupa [el teatro de la segunda mitad del siglo XIX] es posiblemente la menos interesante de nuestra dramaturgia... La literatura dramática de la restauración está completamente muerta; es un auténtico "panorama de fantasmas" " ${ }^{4}$ Y sin embargo desde el estudio literario con vocación sociológica, interesado en lo que la gente hace, comprender las obras calificadas de menores pero aplaudidas por el público, es imprescindible para conocer la cultura -en sentido antropológico- de una época en que el teatro se convirtió en un entretenimiento generalizado entre

1. J. Rubio Jiménez, El teatro en el siglo XIX, Madrid, 1983, p. 19.

2. F. B. Pedraza Jiménez, M. Rodríguez Cáceres, Manual de literatura española, VII. Época del Realismo, Tafalla, 1983, p. 221.

3. Ibidem.

4. Ibidem. 
las diversas capas sociales 5 . Sobre la oportunidad de estudiar el teatro para el conocimiento de la cultura de su época, escribía el propio Clarín en 1892:

No es el teatro, a no ser en manos del genio y en épocas socialmente propicias, el modo literario que refleja lo más delicado y profundo del espíritu estético de un país, pero sí el que habla con más claridad y precisión de las costumbres, del gusto y de otras varias señales de la cultura y del carácter de un pueblo, todas interesantes, no sólo para el crítico de las artes, sino más aún para el historiador político y para el sociólogo ${ }^{6}$.

Para entonces hacía décadas que el público asistía en masa a aquel teatro sensiblero, comercial, moralizante, caricaturesco, tópico, simple, estereotipado, maniqueo, ramplón, según los diferentes juicios que han merecido de la crítica contemporánea los diversos géneros teatrales menores de la segunda mitad del siglo XIX. Fueron dichos géneros teatrales la respuesta de los empresarios teatrales y dramaturgos a una demanda creciente de un público heterogéneo, pero que unánimemente tuvo en el teatro uno de los principales contextos de sociabilidad, recreo, incluso de asociacionismo. El considerable número de teatros o sociedades de aficionados al finalizar el siglo (1296 en total en el año 1902, de los cuales 1061 estaban ubicados fuera de las capitales de provincia), demuestra que el teatro fue uno de los principales medios de comunicación social en una España que seguía asolada por el analfabetismo, y en cuyas provincias el acceso a la literatura encontró un cauce adecuado en el teatro, que se sumaba a las vías tradicionales: sermones, coplas, relaciones y romances de ciego, etc. ${ }^{7}$

La afición al teatro, aunque con altibajos, había ido creciendo a lo largo de todo el siglo XIX. Si en el primer tercio del siglo solo existían en Madrid los teatros del Príncipe y el de la Cruz, antes de 1850 la capital ya contaba con trece salas, algunas de ellas utilizadas por aficionados. En 1890 la gran afición al teatro musical daba para mantener las once salas dedicadas a ese género. En la segunda mitad del siglo XIX el gusto por el teatro se expandió por todas las provincias. En Badajoz, por ejemplo, el número de funciones

5. Un estudio del teatro de la segunda mitad del siglo XIX que pone énfasis en la importancia de la perspectiva no solo literaria, sino ideológica y sociológica, es el de J. Rubio Jiménez, «El teatro en el siglo XIX (1845-1900)», Historia del Teatro en España, tomo II, J. Ma Díez Borque et al., Madrid, 1988.

6. L. A. Clarín, Obras completas, vol. II., Madrid, 2005, p. 761.

7. J. F. Botrel, «El teatro en provincias bajo la Restauración. Un medio popular de comunicación», Bulletin Hispanique, 79, 1977, p. 385. 
fue en aumento desde la única en 1860 hasta superar el centenar en $1885^{\circ}$. En Las Palmas de Gran Canaria pasaron de 16 en 1853 a 84 funciones en $1894^{9}$. Incluso en localidades pequeñas como La Puebla (Orense) o en aldeas como María (Almería), sabemos hoy que no faltaba el teatro. No solo es que llegaran las compañías teatrales a los pueblos, sino que allí existían muchas veces grupos de aficionados con capacidad para cooperar en la misma representación teatral o escenificar ellos mismos las obras que habían tenido éxito en Madrid u otras de producción local. El «yo quiero ser cómico» de Larra realmente llegó a impregnar los sueños y voluntades de gentes de toda condición.

Cierto es que, desde un punto de vista literario, no había demasiada originalidad en la mayoría de piezas. Se siguieron cultivando géneros dieciochescos, como la comedia de magia o los sainetes, y se dio nuevo impulso a otros no menos populares, como el melodrama o la zarzuela, que solamente en las últimas décadas están recibiendo cierto reconocimiento por parte de los investigadores. Las funciones teatrales no solo incluían piezas dramáticas, sino también bailes, actuaciones de prestidigitación o ejercicios gimnásticos, en un popurrí muy del gusto del público, no solo de provincias. Los liceos, casinos, sociedades recreativas, conservatorios, incluso colegios tenían muchas veces salas para los diversos tipos de funciones, y aun no era infrecuente que las casas de ciertos burgueses, aficionados a las letras y la escena, albergaran veladas literarias y teatrillos domésticos. Surgió así, en consecuencia, una producción dramática propicia para el recreo, con obras teatrales ligeras, muchas de raigambre cómica, para satisfacer a un público heterogéneo, pero al que casi siempre movía el simple entretenimiento. No solo el público obrero, del que decía José Yxart en 1888 que acudía con toda la familia ${ }^{10}$, sino también el burgués iba al teatro para pasar un buen rato, sin mayores pretensiones, como deja claro M. de Cavia en 1892:

8. Á. Suárez, La vida escénica en Badajoz, 1860-1886, Tesis de doctorado, Departamento de Literatura Española y Teoría de la Literatura, Facultad de Filología, UNED, 1995, p. 1118.

9. Ma d. M., López Cabrera, El teatro en Las Palmas de Gran Canaria (1853-1900), Tesis Doctoral, Departamento de Literatura Española y Teoría de la Literatura, Facultad de Filología, UNED, Madrid, 1995, p. 133.

10. «La más insignificante delicadeza arranca un aplauso o una lágrima; ninguna pasa inadvertida; el menor rasgo de debilidad o de maldad (tal vez sea lo mismo), lleva el condigno e inmediato castigo en un murmullo de desaprobación. Y estos fallos son unánimes: un público de melodrama, a juzgar por ellos, es una asamblea de santos con sus mujeres y sus chiquillos» (J. Yxart, El año pasado, Barcelona, 1888, p. 97). José Yxart fue uno de los críticos teatrales más relevantes de su época. 


\section{EL TEATRO RELIGIOSO NAVIDEÑO DE LA RESTAURACIÓN}

Bastante bien vestido, bastante bien mantenido, y bastante bien educado -todo ello por punto general- va allí principalmente a solazarse, a pasar en grata reunión unas cuantas horas, a olvidar las peleas de la vida, a ver y oír cosas que le interesen... sin que le exciten demasiado los nervios, ni le obliguen a ir más allá del nivel general de la cultura literaria [...], pero, ¡que no le mareen con 'fórmulas nuevas', que no le perturben con análisis psicológicos demasiado sutiles, que no le den nada en dosis demasiado fuertes, que no le metan en honduras! ${ }^{11}$.

No quería el periodista aragonés ofender ni reprochar cosa alguna al público del Teatro de la Comedia. Simplemente era una rápida «exposición de su manera de ser y por consecuencia de su manera de vern ${ }^{12}$. El teatro se convirtió en lugar de cita y cotilleo, de reunión familiar, de celebración por aniversarios o fiestas, de relajación y de asombro para ver los más variados espectáculos que hacían furor en la época ${ }^{13}$. Porque quizá como en ningún otro momento de la historia teatral, era el público el que marcaba el signo de las obras, y aun los tiempos. En Madrid la temporada daba comienzo en septiembre y duraba hasta junio, pero en las provincias el año teatral de muchas compañías profesionales era más reducido: la mayoría de actuaciones se concentraba en los meses de octubre a febrero. En Badajoz, por ejemplo, se ha calculado que la mitad de todas las representaciones teatrales entre los años 1860 y 1886 se llevaron a cabo en los meses de noviembre, diciembre y enero ${ }^{14}$. Las representaciones aumentaban considerablemente en períodos de ferias y fiestas ${ }^{15}$, sobre todo en los pueblos. Si durante la Cuaresma estaba limitado o incluso prohibido cualquier tipo de representación (aunque se permitieran algunas como los conciertos sacros), los días en torno a las fiestas de Navidad constituían uno de los momentos más prolíficos, tanto para la representación por parte de compañías profesionales, como para los grupos de aficionados, que en colegios, sociedades de recreo, liceos y otros contextos se lanzaban a ensayar e interpretar obras de teatro. Asistir al teatro el 24, el

11. M. de Cavia, «Los teatros. En el de la Comedia», La Ilustración Española y Americana, $n^{\circ}$ IV, 30 de enero de 1892, p. 68.

12. Ibidem.

13. Bailes de máscaras, linternas mágicas, fantasmagorías, experimentos eletroquímicos y de descomposición de cuerpos, cinematógrafos, cuadros disolventes, cuadros vivientes, etc.

14. Suárez, op. cit., p. 1119.

15. Así, por ejemplo, la compañía dramática dirigida por Federico Terol, que actuó desde 1874 a 1880 en el sureste español, hacía coincidir su periplo por diversas fiestas patronales, como se constata en el caso de Baza, Garrucha, Vélez-Blanco y Albox (Botrel, op. cit., p. 386). 
25 de diciembre o en algún otro día de las Pascuas navideñas, incluyendo el día de Reyes, para gozar de alguna comedia, zarzuela u otro juguete cómico, se convirtió casi en un hábito tanto en las grandes ciudades como en las localidades menores ${ }^{16}$.

\section{GÉNEROS DE TEATRO RELIGIOSO NAVIDEÑO}

Sabido es que la zarzuela se dirigió desde el principio a un público amplio, y acogió para ello temas y tonos propios de la literatura y las costumbres populares. La crónica sobre la zarzuela entre los años 1839 a 1863 que dejó escrita el compositor e historiador Francisco Asenjo Barbieri, es una prueba fiable de la importancia que tenía el 24 de diciembre para la zarzuela, así como -ya en la década de los sesenta- los días inmediatamente anteriores y posteriores. A tenor de sus recuerdos, parece que desde la década de los 40 hasta bien entrados los años 60, apenas hubo un solo día de Nochebuena en que no se estrenara una comedia o una zarzuela en alguno de los teatros de la capital. Algunas de ellas eran obras de temática navideña, como las zarzuelas El mesón en Nochebuena ${ }^{17}$ (1843), La Noche Buena ${ }^{18}$ (1847), El turrón de Nochebuena ${ }^{19}$ (1847) o La estrella de Belén ${ }^{20}$ (1866), aunque en muchas otras el trasfondo temático no aludía directamente a las Pascuas. La mayoría tenía, sin embargo, algo en común: eran piezas ligeras y cómicas, compuestas para divertir y hacer reír. Tal era la demanda teatral en esa fecha, que las funciones en los diferentes teatros se solapaban ${ }^{21}$. No faltaban tales días sesiones dobles

16. Como en seguida veremos, en Madrid, entre los ańos 1839 y 1863 , era la función de Nochebuena una de las más solicitadas. En Badajoz, sin embargo, entre los años 1860 y 1875 la representación de Navidad, el 25 de diciembre, despertaba mayor entusiasmo.

17. Zarzuela en un acto, con texto de autor desconocido y música de Iradier. Contiene un coro, un terceto y las canciones La naranjera y El matón de Iradier.

18. Zarzuela con libreto de Mariano Pina.

19. Zarzuela con libreto de Juan de Alba, música de Oudrid.

20. Fantasía bíblica en tres actos de José María Gutiérrez de Alba.

21. «En el Instituto, a 24 de diciembre de 1847, se estrenó La Noche Buena, zarzuela en un acto que va adjunta y cuya música parece que fueron canciones y bailes no compuestos ad hoc, sino ya conocidos. Tuvo buen éxito. El mismo día se estrenó en el Teatro de Variedades otra zarzuela con música de Oudrid titulada El turrón de Nochebuena, cuyo libreto ni sé de quién era, ni he podido adquirir», escribe Barbieri (F.A. Barbieri, Crónica de la Lírica Española y Fundación del Teatro de la Zarzuela (1839-1863), edición crítica, estudio preliminar, notas y relación de estrenos por Emilio Casares Rodicio, Madrid, 2006, p. 37). En la Nochebuena de 1861 se estrenaron hasta tres zarzuelas en los teatros de Jovellanos, del Circo y de Variedades (Barbieri, op. cit., p. 334). 
de estrenos, una en torno a las 4 y otra a las 8 de la noche ${ }^{22}$. En Madrid, sobre todo desde que el 20 de diciembre de 1858 se instalara luz eléctrica en el teatro de la Zarzuela, las noches entre Navidad y Reyes registraban gran afluencia de público, que demandaba una función graciosa y, a ser posible, variada.

Los carteles que anunciaban los diferentes espectáculos son suficientes para hacerse una idea de cómo se procuraba el divertimento. Así, por ejemplo, la función para el 29 de diciembre de 1851 en Valencia, que comenzaba a las 6 de la tarde, incluía el juguete cómico-lírico-bailable Escenas en Chamberi, compuesto de seguidillas bailadas y cantadas, aria, baile de La Gallegada, terceto, baile de Las Manchegas nuevas de Toledo, entre otros. A continuación se ejecutaba una sinfonía y después la pieza en un acto, titulada Un Puntapié y un Retrato. En el intermedio la señorita Quintero bailaba las boleras de la sandunga, antes de dar comienzo la ópera cómica en un acto titulada La paga de Navidad. En esta había coro, dúo del Peluquín, bailes de manchegas, cuarteto, aria y otros espectáculos. Aún quedaría por representarse la comedia de costumbres andaluzas Triana y la Macarena, en la que se bailarían las seguidillas mollares de Sevilla ${ }^{23}$.

Las Pascuas navideñas constituían la culminación del período fuerte en la temporada teatral. De ahí que Barbieri se moleste cuando el Teatro del Circo, casi en bancarrota, le pide una zarzuela «para ponerla en su teatro pasadas las fiestas de Navidad, que, como es sabido, es la peor época teatral del año» ${ }^{24}$. En carta fechada el 27 de diciembre de 1862, Barbieri reprocha a uno de los empresarios del Teatro del Circo que han gastado «el tiempo de la mejor temporada del año» en zarzuelas mediocres de otros autores, «y ahora que viene la peor, os entran las prisas de acordaros de mi música» ${ }^{25}$.

Las Pascuas tenían idéntica importancia para el teatro en las capitales de provincia y en otras localidades menores. Un rastreo exhaustivo por las representaciones teatrales en Badajoz entre los años 1860 y 1875 , demuestra que muchos pacenses ocupaban la tarde del día de Navidad en asistir al teatro ${ }^{26}$. Solían sucederse las funciones varios días más, incluyendo frecuentemente el 28 de diciembre (Santos Inocentes), Año Nuevo y el día de Reyes Magos. El carácter extraordinario y festivo de esas fechas suscitaba el recargar muchas veces la función con la actuación de copleras, bailes y otros

22. Barbieri, op. cit., p. 246.

23. Teatro. Gran Función Escogida y Variada para el Lunes 29 de Diciembre de 1851, a beneficio del público, Valencia: Impr. de J. Ferrer de Orga.

24. Barbieri, op. cit., p. 348.

25. Barbieri, op. cit., p. 351.

26. Otro tanto ha observado Botrel (op. cit., p. 386) en el medio rural. 
espectáculos ligeros en el intermedio. Por otra parte, durante las Navidades, volvían a las poblaciones provincianas los jóvenes que cursaban estudios en las capitales, lo que no pocas veces era motivo para celebrar obras de teatro y veladas literarias, en que éstos actuaban o recitaban poemas ${ }^{27}$.

Como ocurría en las funciones zarzuelísticas de Madrid, algunas de las obras representadas tales días en las provincias no diferían en cuanto al asunto de las que se ejecutaban en otros momentos del año. Y sin embargo también allí había una clara tendencia a poner en cartel obras cómicas, inspiradas a veces en motivos típicos de esa fecha, que aludían a situaciones y contextos costumbristas. Así, el juguete cómico en verso Los aguinaldos de Francisco Pérez Echevarría, representado un Año Nuevo de 1873. Junto a las piezas cómicas y ligeras, tenían cierto arraigo en algunos contextos las obras de vocación moralista y piadosa. En el mismo año de 1873, en el Liceo de Artesanos pacense tenía lugar la representación del drama sacro de Enriqueta Lozano titulado Dios es el rey de los reyes, ejecutado por niños y nińas, que había sido compuesto por la muy religiosa y tradicionalista escritora granadina en 1852 .

De entre todas las obras de temática navideña, las que más gustaban -a tenor de lo que podemos inferir por prensa, carteles y crónicas teatralesfueron los dramas, comedias y zarzuelas inspirados en los antiguos episodios de la Anunciación a los pastores, la Huida a Egipto y la Adoración de los Reyes Magos, en los que junto a la vocación educativa y piadosa se mezclaba la comicidad y la licencia burlesca, más o menos chocarrera. Constituían éstos una especie de autos navideños, al estilo de las farsas, églogas y representaciones del Nacimiento que hunden sus raíces en el tipo de drama que inaugurara Juan del Encina. Muchas compañías de teatro profesionales tenían en su repertorio este tipo de obras religiosas para los días de Pascua, algunas de las cuales estaban adaptadas a uno de los géneros de moda: la zarzuela. El día de Navidad y el de los Santos Inocentes de 1879, por ejemplo, se representaban en Pontevedra zarzuelas sacras como Los pastores de Belén o El Nacimiento del Hijo de Dios ${ }^{28}$, cuya función podía complementarse con algún sainete. Grupos de aficionados dispersos por toda la geografía ensayaban durante días en liceos, casinos o asociaciones recreativas para

27. «La función literario-musical celebrada en el Conservatorio de la Orquesta por los estudiantes de las distintas universidades y escuelas, venidos a Badajoz con motivo de las fiestas navideñas, dedicó la segunda parte a la lectura de diversos trabajos literarios» ( $\mathrm{La}$ Crónica, 3 de enero de 1881, apud Suárez, op. cit., p. 578).

28. Zarzuela sacra en cuatro actos de Manuel María González (T. Ruibal, La vida escénica en Pontevedra en la segunda mitad del siglo XIX, Tesis doctoral, Departamento de Literatura Española y Teoría de la Literatura, Facultad de Filología, UNED, 1997, p. 46). 
representar algún día de las fiestas navideñas un drama religioso, musical o no. En Pontevedra un grupo de aficionados dirigido por el profesor y músico pontevedrés Prudencio Piñeiro, puso en escena en las Navidades de 1868 el auto sacro El Nacimiento del Hijo de Dios o La Adoración de los Santos Reyes ${ }^{29}$. En ocasiones eran llevadas a escena con fines caritativos, como ocurre por ejemplo con La adoración de los pastore ${ }^{30}$ que un grupo teatral de aficionados representó durante varios días de las Navidades de 1891 en las Palmas de Gran Canaria, a beneficio de los asilados en un hospital de la ciudad ${ }^{31}$.

Especialmente numerosas eran las piezas navideñas también para el teatro escolar, representado en el ámbito de colegios, pero también en liceos y salas de teatro. En algunos lugares este teatro navideño recibía el nombre genérico de belén. Sabemos, por ejemplo, que los que se llevaban a cabo en el Colegio Imperial de Huérfanos de San Vicente Ferrer (Valencia), en torno al año 1860, gozaban de gran resonancia en la ciudad ${ }^{32}$. El Nacimiento del Niño Jesús de Vicente Boix, representado en 1861, no es más que una de las numerosas obras navideñas que ininterrumpidamente se escenificarían hasta bien entrado el siglo XX, con títulos como Dios con nosotros (Oller), El Verbo humanado (Joaquín Balader), El hijo del Eterno (Lahoz), La huida a Egipto (José Arroyo), La estrella de Belén y La infancia del Niño Dios (Saiz). El teatro infantil navideńo se repite a lo largo y ancho de la Península: en Pontevedra una compañía infantil, dirigida por Francisco Piñeiro interpretó en la última semana de diciembre de 1865 varias zarzuelas religiosas como Los pastores de Belén, La presentación en el Templo y La degollación de los inocentes ${ }^{33}$, en las que el propio director de la compañía arreglaba la música ${ }^{34}$.

$\mathrm{Si}$ algunos de estos dramas, comedias y zarzuelas podían representarse tanto en contextos religiosos como profanos, tanto para (y con) nińos, como entre adultos, era porque conjugaban la didáctica piadosa con una comicidad de larga raigambre navideña, la cual se suavizaba en los aspectos más irreverentes cuando el momento lo exigía. El estudio de algunas de estas piezas teatrales jocoserias -que han caído hoy en el más absoluto olvido-, demuestra interesantes vínculos con una tradición teatral que, heredera

29. Texto de Adelaida Muñiz y José de la Cuesta con música de T. F. Cajal. Noticia en $E l$ Buscapié $\mathrm{n}^{\circ}$ 87, 28 de diciembre de 1867 (apud Ruibal, op. cit., p. 27).

30. De José María León y Domínguez.

31. La función, estrenada el 27 de diciembre de 1891 en el teatro del Hospital de San Lázaro, se repitió el 30 y 31 de diciembre, y el 6 y 16 de enero de 1892 (López Cabrera, op. cit., p. 92).

32. J. Cervera, Historia crítica del teatro infantil español, Madrid, 1982.

33. Cuadro en un acto de Enrique Zumel y Manuel Sabater.

34. El Restaurador, $\mathrm{n}^{\circ}$ 40, 18 de diciembre de 1965 (apud Ruibal, op. cit., p. 21). 
del drama pastoril navideño renacentista y áureo, siguió viva tanto en el ámbito religioso de colegios, conventos e iglesias, en el profano de las salas de teatro, casinos y asociaciones culturales, como en el teatro popular -a veces callejero e itinerante-, que se mezclaba esos días con el ritual y la fiesta, las coplas, los bailes y las bromas. El teatro navideño, especialmente el que desarrolla los asuntos del drama sacro clásico de Navidad, muestra así una sorprendente homogeneidad de tópicos, temas, personajes a lo largo de los siglos. Cambian, naturalmente, los lugares de representación, el público al que se dirigen, el género literario en el que se inscriben. Pero a veces, farsa, comedia, auto pastoril, drama, zarzuela o diálogo dramático no parecen más que diferentes envoltorios para una singular mezcla de didactismo y humor que se mantiene básicamente inalterada, y que sigue gustando hoy en algunos pocos lugares donde aún se representan obras en las que, junto a la devoción cabe -casi se exige- cierto grado de comicidad chusca.

\section{Piedad y HuMOR: El ESCARNio DEL PECADOR Y EL DiAblo}

El escolapio P. José Felis (Gandía, 1850-1918) fue uno de los autores prolíficos en este tipo de piezas. A partir de 1884 se representarían en el Santo Hospital de Alcira varias zarzuelas suyas del ciclo navideńo, cuya ligazón con los diferentes episodios bíblicos tomados como referente desde el antiguo drama navideño renacentista, se vislumbra ya en los títulos, que se repetían invariablemente: El Nacimiento del Niño Dios, La Adoración de los Santos Reyes, La degollación de los Niños Inocentes y La Huida a Egipto. Aunque no carece de zarzuelas de temática profana ${ }^{35}$, sabemos que al menos las del ciclo navideńo gozaron de enorme popularidad y no solo en Valencia, como demuestra el hecho de que los libretos publicados se editaran varias veces y que se hayan encontrado ejemplares muy lejos de su lugar de edición y venta. Así, la edición que manejo de El nacimiento del Niño Dios, publicado en Valencia en 1892 (la primera es de 1887), perteneció a un tal Jesús María Rodríguez Fernández, párroco en Navelgas (Asturias), coadjutor del Valle de San Agustín en Castro, quien a principios del siglo XX escribía su nombre sobre el libreto. La razón es que en colegios, iglesias y centros de recreo siguieron representándose estas piezas navideńas hasta bien entrado el siglo XX.

35. Taumaturgo de Nápoles, Zarzuela en dos actos (Valencia, 1889); La torre Eiffel, Juguete cómico en un acto (Valencia, 1891); Colón, Zarzuela en tres actos y en verso (Valencia, 1892). 
La zarzuela de José Felis y música de José Silvestre El nacimiento del Niño Dios, fue representada "con extraordinario éxito» ${ }^{36}$, según reza en la portada de su publicación, en el Santo Hospital de Alcira (Valencia) el 25 de diciembre de 1884. El nacimiento del Niño Dios se desarrolla en cuatro actos: «Los pastores en Belén», «La casa de Samuel», «La cabaña de los Pastores» $\mathrm{y}$ "La adoración de los pastores». En ella conjuga los motivos más clásicos del antiguo Officium Pastorum, con escenas tradicionales desde que fueran incorporadas lentamente a través de los Evangelios Apócrifos, y en parte también otros elementos tomados de la comedia de magia, sainetes y otros géneros ligeros. El primer acto representa el consabido argumento de la llegada de José y María a Belén, y sus dificultades para encontrar hospedaje, lo mismo que le ocurre a un grupo de pastores (tres hombres y tres mujeres), cuya bondad contrasta con los dos personajes malignos de la obra: un mesonero y un supuesto amigo de san José, que niegan la posada a los padres del Redentor. Como ocurre en el teatro navideńo desde el Renacimiento, los pastores irrumpen con bailes y canciones, desde el principio de la obra, que comienza con música y con guińos burlescos:

\author{
Música \\ Son los ofrecimientos \\ que hacen los de Belén, \\ corteses cumplimientos \\ sólo por quedar bien. \\ Coro \\ Sinó, venid \\ y lo veréis: \\ ¡Cuánta pamplina \\ hay en Belén! $(5)^{37}$
}

San José y la Virgen, al contrario de lo que ocurre en el teatro navideño entre los siglos XV y XVIII, en el cual son personajes pasivos (muchas veces inexistentes), aquí sí aparecen en escena (buscando posada), aunque como es habitual cederán su protagonismo a los personajes profanos: algunos arquetípicamente malvados (los dos avaros judíos), otros buenos (los pastores)

36. J. Felis, El Nacimiento del Niño Dios. Zarzuela en 4 actos, música de d. José Silvestre, segunda edición, Valencia, 1892.

37. Cito páginas por la edición de 1892 (Felis, op. cit.). 
y aun otros a medio camino, ambiguos como el pastor bobo. Los personajes pecaminosos reciben naturalmente su escarmiento, que es acometido a la manera cómica. El avaro posadero Labán, que se niega a hospedar a José y María, es ridiculizado pronto pues «sale a la puerta, en paños menores», como reza la didascalia (10). Tanto él como Rubén, el amigo de san José que igualmente le niega el techo, reciben su merecido, pues finalmente - por su necedad, avaricia y egoísmo- se ven en la necesidad de dormir al raso $^{38}$. El castigo ejemplar es ejecutado y ambos quedan estornudando a la intemperie ${ }^{39}$. Los pastores, sin embargo, se apiadan de ellos y deciden cantar y bailar para quitarse el frío, a lo que obligan a los dos avaros (20):

\begin{tabular}{|c|c|}
\hline Labán ó Rubén: & $\begin{array}{l}\text { ¡Ay qué noche más perra! } \\
\text { ¡Válgame el cielo! } \\
\text { El viento de esta sierra } \\
\text { es como el hielo. }\end{array}$ \\
\hline Los dos: & $\begin{array}{l}\text { ¡Pobre de mí! } \\
\text { ¡Ay! ¡ya me he constipado! } \\
\text { ¡Pchí! ¡pchí! ¡pchí! ¡pchí! }\end{array}$ \\
\hline Zagal ó zagala: & $\begin{array}{l}\text { ¡Válgales Dios! } \\
\text { Que de una pulmonía } \\
\text { mueren los dos. }\end{array}$ \\
\hline Labán y Rubén: & $\begin{array}{l}\text { ¡Pobre de mí! } \\
\text { ¡Ay! ¡ya me he constipado! } \\
\text { ¡Pchí! ¡pchí! ¡pchí! ¡pchí! }\end{array}$ \\
\hline
\end{tabular}

El cuadro no es patético sino claramente burlesco, especialmente por los estornudos de los judíos mientras danzan. Estos son los personajes a costa de los cuales se ríe el público. Cuando en la siguiente escena viene la ronda armada, el centurión Ayax lisonjea a las pastoras que esperan a sus maridos, los cuales han ido a buscar a José y María, pero cuando los estornudos de

38. Cuando uno de los pastores (Elicier) llama a su puerta, el mesonero sale para comprobar que los dracmas ofrecidos por aquel son auténticos y la puerta -castigo divino- se cierra tras él, dejándole a la intemperie. «iTodos iguales!» (15), exclama la pastora Rebeca. Cuando su vecino Rubén sale enojado para enfrentarse con el mesonero por el escándalo que ha formado de noche, éste le cierra la puerta igualmente, quedando los dos fuera. Ni uno ni otro -ambos judíos- pueden volver, Rubén porque se encontraba solo en casa, el posadero porque había dado órdenes a sus criados de no abrir a nadie «aunque llamase / a la puerta el mismo Dios» (17).

39. «Que tiemblen. Dios les castiga / a sufrir con más rigor / el frío que martiriza, / por culpa de estos bribones, / a dos pobres que pedían / un pobre albergue en sus casas». 
Labán y Rubén delatan que se encuentran escondidos, éstos son tomados por fantasmas y los soldados «los corren a palos» (23), provocando la huida quejumbrosa de los dos pecadores.

Ambos irán a buscar refugio en pańos menores a casa de Samuel, el nigromante, cuñado de Labán, en cuya casa llena de botes y reptiles disecados, comienza el segundo acto, en el que no faltan los rasgos tomados de la comedia de magia. Ante los ruegos de su mujer, Tamar, el nigromante -a regañadientes- accede a darles cobijo en su propio laboratorio, pero anticipa que tendrán su merecido ${ }^{40}$. Es ahora cuando comienzan las verdaderas desgracias de los dos avaros, cuyo castigo se ejecuta con diversos escarmientos cómicos. Dan con las costillas en el suelo al romperse las sillas, nieva sobre ellos cuando se tapan con la manta en el suelo, y desaparecen como por arte de magia sendas túnicas con las que ambos se intentan abrigar. Labán, el malvado soberbio, decide quitarse el frío con un tonelillo que huele a ańejo. «Al ir a sacar vino, el tonel se convierte en una cabeza monstruosa arrojando fuego por la boca», según reza la anotación (40). Es el mismísimo Satán, que entabla diálogo con los dos castigados, advirtiéndoles que, testigo de sus maldades, quiere ser su amigo. Como es habitual en las representaciones navideñas, el diablo será vencido por san Miguel, que espada en mano le hace huir. No acaba ahí la tramoya risible que tanto gustaba al público. Cuando el arrogante Labán culpa a Samuel de lo sucedido e intenta matarle, su mujer Tamar lo impide pero, al contacto con el judío maldito, le salen de repente unas enormes y deformes narices. Para colmo de maldad, Labán y Rubén usurpan la habitación y la cama de ésta, donde se refugian. Con vistas a que desaparezca el horrible aspecto de su mujer, Samuel se retira a su aposento e invoca a Satanás con un ritual mágico ${ }^{41}$. Luzbel aparece y está de acuerdo no solo en que las Furias saquen a los dos tunantes de la habitación y los arañen hasta no dejarles orejas ni nariz, como desea un irritado Samuel, sino que propone «darlos de palos / hasta que mueran». Samuel, que no tiene tan perversas intenciones, llega a un acuerdo con el diablo. Los dos avaros serán llevados lejos a las montańas, a cambio de que Luzbel haga desaparecer la deforme nariz a su mujer. Cantando hace salir Luzbel a las Furias, las cuales aparecerán en la siguiente escena por debajo de la cama, en

40. «Y esto es lo que a mí me pasa / cuando, a ruegos de Tamar, / a dos tunos voy a dar / alojamiento en mi casa. / ¡Pero a estas horas venir / a incomodarme los dos! / ¡Esto es serio! ¡Vive Dios! / ¡Que se van a divertir!» (30).

41. «Coloca sobre una trípode un pebetero con fuego, y con una varita señala un círculo a su alrededor, y echando un puñado de incienso pronuncia el conjuro siguiente (didascalia, 53): 'Rey del inmenso / Báratro obscuro, / yo te conjuro / por este incienso / que al fuego arrojo, / para que digas / a quien hostigas / con tanto enojo'». 
la que duermen Labán y Rubén. Éstas «bailarán alrededor de ellos, dándoles pellizcos y cantando» (57):

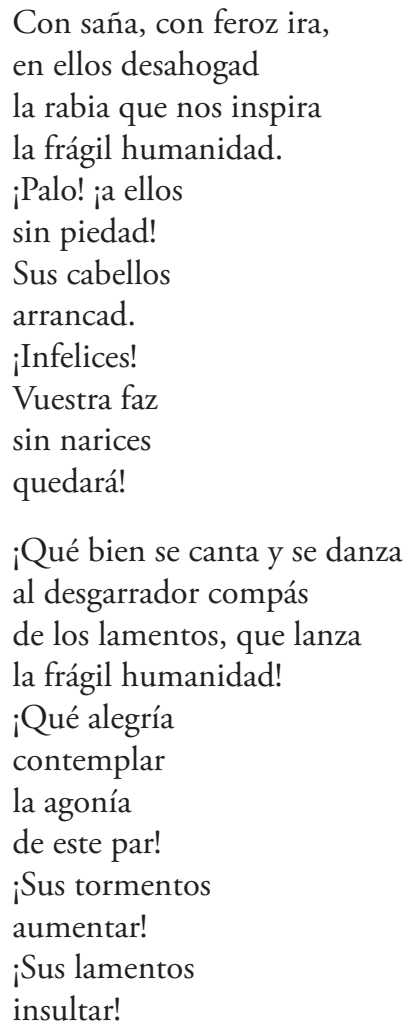

Solo el deseo de Samuel para que cesen, salva a los dos avaros, que no paran de quejarse mientras reciben la paliza diabólica. Una vez que Luzbel cumple su promesa de quitarle la grotesca nariz a su mujer, Samuel muestra su voluntad de romper el pacto con el diablo que hizo por su afición a las ciencias, ante lo cual se adelanta san Miguel que rasga el papel del diabólico pacto, arrojándolo a los pies de Luzbel. Cuando éste les anuncia la buena nueva, Samuel y Tamar se arrodillan y cantan un villancico piadoso, flanqueados por el arcángel, tras lo cual cae el telón del segundo acto.

El elemento bufo de estas obras, incluyendo las diabluras de personajes demoníacos con profusión de lo que hoy llamaríamos efectos especiales, merecían el desprecio de algunos críticos que censuraban al «inverosímil mamarracho que ofende tanto la moral como el sentido común» (Crónica de 
Badajoz, 18 de diciembre de 1864$)^{42}$. Y sin embargo, el escarnio del malvado, frecuentemente con la intervención de personajes diabólicos que le infligen el castigo, es tópico teológico bien antiguo ${ }^{43}$, adaptado muchas veces al teatro religioso, lo que se retomará en comedias de magia y obras jocoserias navideńas, como esta zarzuela. Acaso hoy choque a algunos sectores de la población que los más sagrados misterios de la religión se traten entre burlas y veras, pero este registro ha gozado de enorme popularidad desde siglos, y no precisamente entre los sectores poco piadosos. Bastará recordar que en fecha tan temprana como 1402 los hermanos de la Pasión representaban farsas de la Pasión y el Antiguo Testamento en París, en algunos de los cuales -como el que se atribuye al obispo de Angers- intervenían el Padre eterno y Jesucristo, junto con Lucifer, Satanás, la Magdalena y algunos de sus amantes. A lo largo de la pieza teatral, Lucifer daba una paliza a Satanás por no tentar a Cristo con éxito, la hija de la cananea con los diablos en el cuerpo se desahogaba diciendo mil disparates, el alma de Judas que no podía salir por la boca que había besado a Cristo se escapaba por otra parte, llevándose en su salida las entrañas del apóstol traidor, mientras Satanás volaba al pináculo con Jesucristo a cuestas. La comedia de magia actualizaría algunas de estas escenas, cuando se disponía de mayores posibilidades escénicas. Y otro tanto hacía el teatro religioso navideńo. Las sucesivas desgracias de los dos avaros en la zarzuela de José Felis se enmarcan en un sentido didáctico-religioso tan antiguo como el que los castigos sean escenificados para despertar la risa del público. La paliza de los soldados y la buena tunda que reciben de las Furias son elementos de escarnio risible, tanto como el andar en paños menores o los diferentes costillazos que se dan a lo largo de la obra. El otro foco de humor viene protagonizado por la actuación del pastor bobo.

\section{EL PASTOR BOBO}

El tercer acto de El nacimiento del Niño Dios se desarrolla en una cabaña de pastores, a la que llegan desde Belén los mismos bondadosos personajes que en el primer acto, con sus cayados, zurrones y mantas. Es, de todos los actos, el que más directamente está inspirado en las églogas y farsas

42. Suárez, op. cit., p. 891.

43. Por poner un solo ejemplo, el prolífico Juan Eusebio Nieremberg escribe en 1638: «... pasa en los pecadores, que con la monstruosa fealdad de sus pecados, ahuyentan los santos ángeles y llaman a sí á los demonios, que por permisión divina, cuanto más pecados hace uno, más licencia tienen sobre él; y no un demonio, sino muchos acuden» (V. P. J. E., Nieremberg, Aprecio y estima de la Divina Gracia, Madrid, sin fecha, p. 328). 
navideñas renacentistas. Irrumpe aquí un personaje tan caricaturizado como imprescindible en la comedia navideña de los siglos XV en adelante: el pastor bobo ${ }^{44}$, el auténtico protagonista del tercer acto. A semejanza de los tipos estereotipados difundidos por Juan del Encina, Lucas Fernández, Diego Sánchez de Badajoz y otros que les siguieron, el de esta zarzuela es un dormilón, gandul, borrachín, bravucón y se muestra siempre presto a tomarse a guasa todo lo que ocurre alrededor. Por eso cuando cuenta los increíbles sucesos que ha presenciado, nadie le cree: chacales y otras alimañas bailando con el ganado, el desierto cubierto de flores y, naturalmente, hermosas visiones bajando del cielo mientras allá en Belén se oye música y destellan luces misteriosas. "Hoy has levantado el codo" (68), afirma Jacob, el pastor incrédulo, pero Gedeón, el pastor bobo, aun reconociendo que ha bebido, asegura estar sereno. Como prueba de ello, se presta «a dar una buena nueva». Cuando todo el mundo -incluyendo naturalmente los espectadores- espera que se anuncie el nacimiento del Mesías, el burlón pastor da su particular buena nueva:

Sabed que este año, irá muy barato el vino. ¿Y no os alegráis? (68)

La comicidad prosigue cuando se constata el motivo en que se funda el pastor Gedeón para pronosticar un buen año de vino, que no es otro que su malinterpretación de las señales extraordinarias que, según los Evangelios apócrifos, habrían de anunciar el nacimiento de Jesús. Pero el bobo no atisba a comprender los signos sagrados. Si el ganado anda revuelto, es porque se barrunta tormenta; y si inexplicablemente brotan los vińedos y en cada sarmiento hay racimos en la estación invernal, se frota las manos con la cantidad de vino de la próxima añada y se echa a dormir. Tan bobo es que pretende incluso cortejar a la Virgen, para lo cual bebe vino con vistas a «tomar fuerzas» y llegar a Belén ${ }^{45}$, además de darse un atracón de migas.

44. Sobre el pastor bobo en los siglos XV a XVII hay una abundante bibliografía. La obra principal sigue siendo The Pastor-Bobo in the Spanish Theatre before the Time of Lope de Vega, de John Brotherton (Londres, 1975). Puede verse también J. P. Wickersham Crawford, «The Pastor and Bobo in the Spanish Religious Drama of the Sixteenth Century», Romanic Review, 2, 1911; y F. Cazal, «Del pastor bobo al gracioso: el pastor de Diego Sánchez de Badajoz», Criticón, 60, 1994.

45. «¿Quién te espera [en Belén]?», pregunta el mayoral Roboám. Y Gedeón contesta: "Una joven muy hermosa / que sin amparo se encuentra. / Quiero llevarle un cordero, / y decirles cuatro frescas / a los tunos de Belén». 


\section{EL TEATRO RELIGIOSO NAVIDEÑO DE LA RESTAURACIÓN}

Gedeón: ¡Buenas están! [las migas] ¿Qué no llega la bota aquí?

\section{(le dan la bota y bebe)}

Lía: ¡Cuánto bebes!

Gedeón: ¡Están las migas tan secas, que si antes no las remojas!

En su afán por los placeres mundanos (la comida, la bebida, la siesta), en contraposición a lo espiritual del misterio navideño, el pastor bobo zarzuelístico no difiere del que encontramos en los dramas navideños entre los siglos XV y XVII, muy especialmente en uno, que parece tener presente en todo momento José Felis: el Auto o farsa del Nacimiento de Nuestro Señor Iesu Christo de Lucas Fernández (1474?-1542). En éste el pastor Pascual entra en escena, quejándose del frío y la lluvia, mientras se muestra decidido a conjurar el mal tiempo con la bebida y la comida ${ }^{46}$. No menos tópico es su afán de echarse a dormir, uno de los rasgos más habituales del pastor bobo, usado por varios dramaturgos, como Diego Sánchez de Badajoz o el propio Lucas Fernández. En su Auto o farsa del Nacimiento presenta a un bobarrón perezoso ${ }^{47}$, Llorente, al que Pascual despierta con insultos. Algunos pasajes de este texto son recreados en la zarzuela. "Hideputa, medio bobo, / si agora viniera el lobo, / ¡quál te parara el ganado, / mordiscado y sobajado!» (vv. 78-82), regaña Pascual al pastor dormilón en el Auto de Lucas Fernández, a lo que éste contesta: «No te puedo aún otear, / que tengo aquestas pestañas / tan pegadas con lagañas... / No las puedo despegar» (vv. 86-89). El diálogo propuesto por José Felis (66-67) es igualmente burlesco, pero bajado de tono, sin referencias grotescas ni insultos explícitos, aunque conservando la bobería del pastor:

$$
\begin{array}{ll}
\text { Jacob: } & \text { ¡El lobo!... } \\
\text { Gedeón: } & \text { ¡Bah! ¡bah! Durmamos. }
\end{array}
$$

46. «Digo que de aquí adelante / quiero andar más perpujante / comer, beber: de contino: / tassajo, soma y buen vino. // comer buenos requesones, / comer buena miga cocha, / remamar la cabra mocha / y comer buenos lechones...» (vv. 24-31).

47. Así le moteja Pascual, además de: «Hideputa, medio bobo» (v. 78). 


\begin{tabular}{|c|c|c|}
\hline Jacob: & \multicolumn{2}{|c|}{$\begin{array}{l}\text { Date prisa, remolón. } \\
\text { Levántate, dormilón. } \\
\text { ¿Estás sordo? Ven corriendo. }\end{array}$} \\
\hline Gedeón: & \multicolumn{2}{|c|}{ No oigo bien, que estoy durmiendo. } \\
\hline Jacob: & \multicolumn{2}{|l|}{$\begin{array}{l}\text { Que te doy un puntapié, } \\
\text { vamos pronto, necio. }\end{array}$} \\
\hline Gedeón: & ¿Qué? & (Riéndose) \\
\hline Jacob: & \multicolumn{2}{|l|}{ ¡Me gusta! ¡Y se está riendo! } \\
\hline Gedeón: & ¡Ah!... ¡ah!... ¿Eres tú? & (Desperezándose) \\
\hline Jacob: & \multicolumn{2}{|l|}{ Ven, que el lobo... } \\
\hline Gedeón: & ¿Dónde? ¡qué miedo! & (Tapándose) \\
\hline Jacob: & $\begin{array}{l}\text { Cercado } \\
\text { lo tenemos en el prado. }\end{array}$ & \\
\hline Gedeón: & ¿Y es feo? & \\
\hline Jacob: & $\begin{array}{l}\text { ¡No hagas el bobo, } \\
\text { que la badana te sobo! } \\
\text { ¡Álzate pronto de ahí! }\end{array}$ & \\
\hline Gedeón: & $\begin{array}{l}\text { Mientras me amuelas así } \\
\text { y descansar no me dejas, } \\
\text { pudieras de las orejas } \\
\text { haberlo traído aquí. }\end{array}$ & (Vuélvese a echar) \\
\hline
\end{tabular}

En el Auto de Lucas Fernández, ambos pastores -el glotón y el dormilónsienten esa noche una rara turbación, pero como le ocurrirá al igual de ignorante pastor de la zarzuela, no encuentran explicación a los extraños fenómenos y deciden optar por el entretenimiento ${ }^{48}$. Frente a ellos aparece en el Auto de Lucas Fernández, el pastor devoto, Juan del Collado, que intenta convencerles de la buena nueva, y al que los dos pastores burlones motejan de mamaburras, hydeputa, cara de caniñete y majadero. Es contraposición

48. Con diversos juegos: el estornija, el palo, el saltabuytre, la chueca, juegos rústicos, por cierto, en varios de los cuales las caídas y las risas estaban aseguradas. 
frecuente en muchos dramas navideńos de los siglos XV en adelante ${ }^{49}$. El mayoral Roboám encarna en la obra de José Felis al pastor sabio y devoto. Él sí sabe interpretar el significado sagrado de los chacales convertidos en mansos corderos (80) y cita incluso la profecía contenida en Isaías ${ }^{50}$. Pero no es a él a quien se le aparece el ángel con la buena nueva, sino al bobo, que en su ignorancia huye despavorido al ver «un ángel echando rayos» (80). José Felis no olvida de introducir en su zarzuela el intercambio de insultos y pullas, tópico frecuentísimo en el teatro pastoril del Renacimiento en adelante.

$\begin{array}{ll}\text { Roboám: } & \begin{array}{l}\text { Calla, Gedeón. Oveja } \\ \text { que bala, pierde bocado. }\end{array} \\ \text { Gedeón: } & \text { Ya lo sé; pero esa necia... (a Lia) } \\ \text { Lía: } & \text { ¿Necia yo? ¡Calle el mostrenco! } \\ \text { Gedeón: } & \text { ¡Presumida! } \\ \text { Lía: } & \text { ¡Tragón! } \\ \text { Gedeón: } & \text { ¡Fea! }\end{array}$

Ajustándose a un ambiente mucho más mojigato y donde la chocarrería no podía llevarse tan lejos como en los siglos que ensalzaron lo jocoserio y la mezcla de géneros, el escolapio Felis parece querer mantener el tono rústico, pero en su obligación de edulcorar lo malsonante e irreverente, pierde la chispa y gracia de las obras que le servían de modelo. Los paralelismos no acaban ahí. Como en muchos dramas navideños renacentistas y barrocos, el pastor de la zarzuela saca provecho a veces de su bobería. Así, cuando se atraganta con las migas -fingidamente o no- sus compañeros se ven obligados a darle la bota para que trague. "iMira el simplón! -protesta Jacob- «a ese paso / a todos así nos dejas...» (76). Por pitos o por flautas, el simplón consigue dar más tragos a la bota que el resto de comensales juntos,

49. Por ejemplo en el Auto Pastoril Castellano de Gil Vicente, donde «um pastor inclinado à vida contemplativa», según reza en la Copilaçam, de nombre Gil Terrón, se contrapone a Bras, que anda «siempre en bodas, / corriendo toros y vacas».

50. «Oid el hermoso canto / con que el Profeta Isaías, / la venida del Mesías / anuncia con gozo santo: / 'El cordero y el león / juntos los dos pacerán / los yermos florecerán / como el lirio de Sarón. / El solitario desierto / se conmueve y alboroza, / todo el mundo paz goza...» (Isaías XI, 6; XXXV). 
y tan alegre está que incluso improvisa un brindis laudatorio a la joven bella, pura y graciosa (la Virgen). Puesto que Roboám sugiere velar toda la noche, el bobo, medio ebrio, propone bailar para «que se baje, / saltando, el vino á las piernas» (77). Y tal es su espíritu festivo que acaba contagiando al resto de pastores, él bailando y entonando unas seguidillas populares y el resto de pastores cantando a coro y «dando palmadas mientras baila Gedeón» (77):

$\begin{array}{ll}\text { Gedeón: } & \begin{array}{l}\text { Cuando visita el vino } \\ \text { mis pantorrillas, } \\ \text { sólo me gusta un canto... } \\ \text { las seguidillas. } \\ \text { Cantad, pastores, } \\ \text { que esta noche las bailo } \\ \text { de mil amores. }\end{array} \\ & \text { ¡Ole zagales! } \\ \text { Todos: } & \begin{array}{l}\text { Con el vino y el canto } \\ \text { se van los males. }\end{array} \\ & \text { Cuando el vino se sube } \\ \text { Gedeón: } & \begin{array}{l}\text { a mi cabeza, } \\ \text { me parece que bailan } \\ \text { sillas y mesas. } \\ \text { Cantad, pastoras, } \\ \text { que canto no tenemos } \\ \text { a todas horas. } \\ \text { Todos: } \\ \text { ¡Ole, zagalas! } \\ \text { Para bailar, el vino } \\ \text { suele dar alas. }\end{array} \\ \end{array}$

En el cuarto acto («La Adoración de los Pastores») hace aparición de nuevo Satanás, que convence al pastor bobo para que vuelva a casa y no pierda el tiempo yendo a Belén. Dirigiéndose a los diablillos, Luzbel entona su arenga triunfal. Para celebrar el triunfo, los diablos bailan, antes de que se pierdan para engañar al resto de pastores. La didascalia especifica explícitamente dónde debe ir el «baile de diablos», pero el autor, probablemente dubitativo sobre la conveniencia de lo que podría ser visto como disparatado, añade: «Si no hubiera baile debe terminar esta cuarteta así: No hay duda que triunfaremos» (86).

La pérdida del cordero con que el bobo iba a obsequiar a María le sirve al autor para representar la siguiente escena cómica, desarrollada con equívocos. 
Acechando, el bobo se topa con el mesonero Labán, a quien en la oscuridad de la noche toma por su cordero extraviado. Éste «desciende del monte a gatas como escondiéndose» (didascalia 90), lo mismo que hace Gedeón. Cuando el pastor bobo remeda el balido de la oveja («iBé!»), Labán contesta con idéntico sonido, queriendo significar «Id». El encuentro no puede ser más ridículo, aunque algo pueril:

Labán:

Gedeón:

Labán:

Gedeón:

Labán:

Gedeón:
¡Bé! (Id)

¡Ya te lo diré!

¡Si el pobre se habrá creído

que soy su madre! ¡Bé!

¡Bé!

¡Ah pícaro! ¡Ya te tengo!

(Echándose sobre Labán).

¡Ay Dios santo! ¡Yo no soy!

¡Ah!... ¿Qué es esto? ¡Dios me ampare!

(Retrocediendo asustado)

No me engaño ¡vive Dios!

¡En hombre se ha trasformado mi cordero!

El humor absurdo juega con la imagen del cordero (de Dios) convertido en hombre, que Gedeón, en su simplicidad, toma literalmente. Pero el simple, pasado por el cedazo bucólico, es también el inocente, el privado de maldad. El avaro Rubén será quien encuentre al cordero y dará ocasión a Gedeón a mostrar su cara bondadosa, pues éste le asiste con su bota para que se caliente.

$\begin{array}{ll}\text { Gedeón: } & \text { Bebe. Más, más... que esta noche } \\ & \text { es preciso que tomemos } \\ & \text { una media papalina, } \\ & \text { y el grande acontecimiento } \\ & \text { celebremos como hermanos (95). }\end{array}$

Como es habitual en el drama navideño desde antiguo, el pastor bobo acaba convenciéndose del nacimiento del Mesías, y juntos (el bobo y los dos malvados) bajan a Belén a adorarle, después de que haya llegado ya el resto 
de pastores. Son las dos últimas escenas de la obra. Los «rudos, humildes pastores» (100) entablan un diálogo con la Virgen y ofrecen cada cual su alabanza, amén de las rústicas dádivas al Niño: una cesta con pan o unas orcitas de leche y de miel. El pastor bobo y los judíos malos entran en la última escena. Aún hay tiempo para que Gedeón despierte la sonrisa del público con su inocencia, pues cuando sus hermanos pastores se asombran de que Labán y Rubén tengan la vergüenza de entrar, exclama: «¿Por qué? ¿Porque van tan frescos?» (102). Es el pastor bobo quien en última instancia obliga a los dos malvados a postrarse ante el niño, y es él también quien toma la iniciativa para un último baile (una jota) con que los pastores ponen el colofón a la zarzuela.

Como ocurre en el teatro navideño del Renacimiento y el Barroco, los pastores rústicos son elemento imprescindible en el del siglo XIX. Incluso en los más píos, como los que firmaba sor F. G. L., religiosa del convento de Dominicas de Santa Rosa de Zaragoza ${ }^{51}$, la rusticidad de los pastores, especialmente en sus expresiones toscas y sus cantares y bailes, dan siempre un toque de algarabía, que contrasta con la candidez y la moralina fácil de la obra. En otras, como las de Felis, los pastores no solo encarnan al humilde siervo de Dios, sino que, rememorando la antigua tradición del pastor bobo, aparecen para cometer disparates y decir tonterías.

La importancia del pastor bobo explica que sea el único rústico que aparezca en La Adoración de los Santos Reyes, segunda parte del Nacimiento del Niño Dios, zarzuela del mismo autor, representada también en el Teatro del Santo Hospital de Alcira el 6 de enero de 1885, es decir doce días después de la zarzuela que hemos analizado anteriormente ${ }^{52}$. El desarrollo de la acción se enmarca dentro de la tradición del Ordo Stellae o Adoración de los Reyes Magos, escenificado desde al menos el siglo XI en el oficio de Maitines de la fiesta de Epifanía, el 6 de enero, y que al igual que la Adoración de los pastores daría lugar a un buen número de dramas desde el siglo XV. Se

51. Por ejemplo en la comedia Una Noche-Buena: Ventura (pastor): - Pero imos de dispreciar / tan sorprendente musica? / ¡Vaya una cosa bonica! / No, no, vamos á bailar». Pastora $1^{\mathrm{a}}$ : -«Lo que es si entre ceja y ceja / se te mete á ti una cosa...». Ventura:-«Chica, ¡no seas tan sosa! / ven y serás mi pareja» (bailan y cantan animando la escena) (F. G. L., religiosa del convento de Dominicas de Santa Rosa de Zaragoza, Una Noche-Buena. Comedia en un prólogo, tres actos y cinco cuadros y en verso, Zaragoza, 1890, p. 31).

52. Cito por la segunda edición, de 1892: J. Felis, La Adoración de los Santos Reyes (Segunda parte del Nacimiento del Niño Dios). Zarzuela en un acto, segunda edición, Valencia, 1892. Ambas zarzuelas (El Nacimiento del Niño Dios y La Adoración de los Santos Reyes) se vendían en la época por una peseta cada una en la casa editorial de D. Pascual Aguilar, Valencia, tal y como publicaba en un anuncio La Ilustración Española y Americana (30 de noviembre 1891, $\mathrm{n}^{\circ}$ XLIV, p. 342). 
atiene Felis en su zarzuela a las escenas habituales en el género: lamento del turbado Herodes y adulación de Doris; anuncio de la presencia de los Reyes Magos y encuentro con éstos; consulta sobre la profecía a Samuel, Anael, Misael, Jerón y otros doctores de la ley; adoración de los Reyes y vuelta de éstos sin pasar por el palacio de Herodes, al ser alertados por un ángel. Esta trama estereotipada habría de aburrir al público, si no fuera por la aparición intermitente del pastor bobo, oponiendo el toque burlesco a la tensión dramática de un iracundo Herodes, omnipresente en la obra.

Detenido por el centurión Ayax al estar pregonando medio loco y borracho la buena nueva, el pastor bobo -el mismo Gedeón- es presentado ante Feroras e Isacar, hermano de Herodes y jefe de las tropas respectivamente, a los que vuelve loco con sus boberías.

$\begin{array}{ll}\text { Feroras: } & \begin{array}{l}\text { Decid pronto, } \\ \text { y dejad de hacer el tonto. }\end{array} \\ \text { Gedeón: } & \text { ¿Yo tonto?... Diga, nostramo, } \\ & \text { si en agraz está la vid } \\ & \text { ahora, ¿cuántas cosechas } \\ & \text { habrá ogaño? A ver si echas } \\ & \text { esa cuenta... Discurrid... } \\ & \text { ¡já! ja! jjá!... ¿Y tú sabes tanto? (13) }\end{array}$

Cuando Feroras le amenaza con el calabozo si no desvela el paradero del Mesías, el pastor borracho juega con los nombres de Matatías (el personaje bíblico) y Matías, el tabernero donde no olvida nunca parar cuando baja a Belén.

$\begin{array}{ll}\text { Feroras: } & \begin{array}{l}\text {..si no me dices a dónde } \\ \text { has ido a ver al Mesías. }\end{array} \\ \text { Gedeón: } & \begin{array}{c}\text { ¿Yo? ¡sí! ¡calla!... Matatías, } \\ \text { ¡tiene un vinillo! (13) }\end{array}\end{array}$

A pesar de las amenazas («Contesta y no hagas el tonto, / si no quieres llevar palos»), el pastor prosigue con incongruencias y malentendidos, tópico cómico tradicional en el pastor bobarrón clásico:

Isacar: $\quad$ ¡Pues si está como una cuba!

Gedeón: ¡Qué racimos habrá de uva! Le voy a decir a Herodes que ahorque a los taberneros si venden el vino aguado. (14) 
Pero no es tan bobo el pastor, ni tan simple, ni tan borracho. Llevado a los calabozos, se encuentra con Samuel, a quien confiesa su astuto plan: creyendo los esbirros al prenderle que estaba loco y borracho por los brincos y atropellos que daba al seguir a los Reyes Magos, decidió fingir ese papel para evadirse de tener que revelar el paradero de Jesús (23). La estratagema surtirá efecto. Y así, cuando el propio Herodes saca del calabozo a Gedeón y Samuel, para interrogarles en presencia de los adivinos, el fingido borracho logra zafarse de nuevo con respuestas incoherentes, permitiéndose incluso el trato familiar con Herodes («si vienes, yo te convido») cuando éste les despide. Las chocarrerías del pastor bobo se repiten de nuevo en la adoración en el Belén, en contraste con las alocuciones solemnes de Samuel y los Reyes Magos (32).

Naturalmente José Felis no fue el único dramaturgo que siguió utilizando la comicidad tradicional del pastor bobo, aunque limando todo aquello que podía ser excesivo para las mentes conservadoras de la época. Otro ejemplo es Francisco Gras y Elías (1850-1912), autor de varias piezas teatrales navideñas como El nacimiento del hijo de Dios ${ }^{53}$ o Los Pastores de la Judea ${ }^{54}$. En esta última, las escenas jocosas y risibles protagonizadas por los pastores (que en ocasiones nada tienen que ver con el argumento principal navideño), así como la pugna entre San Miguel y Luzbel, conforman de nuevo el núcleo de la obra, mientras que José y María tienen otra vez un papel pasivo, aunque acaben aglutinando en torno al Nacimiento a todos los personajes. Como era de esperar, el novelista, poeta, historiador y dramaturgo catalán ${ }^{55}$, no se olvida de introducir desde el principio al pastor bobo, de nombre Batillo, que se erige -como en la zarzuela de Felis- en el personaje que dinamiza la obra y despierta la risa entre el público. Como es habitual en el género, éste es un personaje ambivalente: feo, es motejado por la pastora: «más parece una espuerta / que rostro humano» (8), «un pedazo de atún, / y habla porque tiene lengua» (8), y sin embargo en el cara a cara sale siempre airoso lo que suscita que otro pastor -Lisardo- diga de él que es «mozo de ingenio, / aunque de rudas maneras» (8-9). Con vistas a reírse de él, Lisardo propone nombrarle jefe de la tribu, solamente para ver «cosas chistosas» (9). Aunque con la oposición de uno de ellos, Caramillo, quien no aguanta contemplar

53. Ésta se representó, por ejemplo, en la noche de Reyes de 1870 en el Teatro del Campo de San Juan (Badajoz).

54. F. Gras y Elías, Los Pastores de la Judea. Drama original en dos cuadros y en verso, Barcelona, 1900. Por esta edición cito.

55. Otras obras suyas en verso: Notas perdidas, Romances de Corte y Villa, La Quinta Samá, Capullos y Besos, Sonrisas, La Paz y la Guerra. 
semejante «mochiganga» (13), la proclamación del nuevo rey se lleva a cabo, remedando la tradición de elegir una autoridad burlesca, costumbre que se remonta al Medievo, y aun con pervivencias en la actualidad ${ }^{56}$. En la pieza de Gras y Elías las zagalas y pastores le colocan los atributos de su reinado: el birrete, una lustrosa capa, una honda, el caramillo de caña, el cayado, el morral, después de lo cual el recién coronado Batillo celebra bebiendo (14):

$\begin{array}{ll}\text { Batillo: } & \text { Yo empino la calabaza, } \\ & \text { que es mi dulce compañera } \\ & \text { cuando vivo entre las matas. }\end{array}$

(Bebe.)

Cuando aparecen San Miguel y Luzbel -el uno anunciando el próximo nacimiento del Mesías, y el demonio (vestido de leñador) negándolo-, Batillo es el interlocutor y ejerce realmente de jefe de pastores, ordenando que se prenda y ate al diablo, con lo que acaba el primer cuadro. En el segundo («La Adoración») se suceden una nueva pelea entre el arcángel y el diablo, la tentación a la que éste somete al pastor Caramillo para que mate al rey pastor (Batillo); la Anunciación del arcángel ante una risueña gitana; y finalmente la Adoración de los pastores ante el pesebre. De nuevo es el pastor cómico quien lidera al grupo para acabar alabado por todos los pastores y aun por el mismísimo San Miguel (27). Y ello a pesar de que no cesan sus estrafalarias intervenciones, como la sugerencia de que los pastores «con esas melenas, / y con esas barbas / tan sucias y feas» se den un paseo por la aldea para que les corten allí «un poco las cerdas» (27). Mientras los pastores -humilde pero solemnemente- ofrecen al Niño las habituales dádivas (pañuelos, manteca, un jarro de leche, lana, miel, queso, roscas), el mojigango Batillo abre el cortejo con una nueva bobería rústica:

56. J. Caro Baroja, El Carnaval (Análisis histórico-cultural), Madrid, 1986. Se inspira Gras y Elías, pues, en una costumbre festiva navideña que en su época tenía mucho más arraigo que hoy. Por poner un solo ejemplo, en Navaleno, un pequeño pueblo pinariego entre Soria y Burgos, pervivió hasta mediados del siglo XX la costumbre conocida como el reinado. Entre los mozos del lugar era elegido cada año un rey, que ejercía de autoridad burlesca durante las Pascuas, y al que junto con su séquito y dos bobos se le permitían ciertas licencias bromistas contra las autoridades (el cura, el boticario, el alcalde), en el típico clima carnavalesco propio de estas fechas. Es una versión más de las diferentes tradiciones navideñas que, bajo la lógica de la subversión simbólica, elevan de status al que está abajo, quien reina efímeramente durante los días de Pascua, elegido como rey de fabes, obispillo, animero mayor u otra denominación (A. del Campo Tejedor, "Mal tiempo, tiempo maligno, tiempo de subversión ritual. La temposensitividad agrofestiva invernal», Revista de Dialectología y Tradiciones Populares, 61, $\left.1^{\circ}, 2006\right)$. 


$\begin{array}{ll}\text { Batillo: } & \text { Buenas noches, don José, } \\ & \text { y muy felices, doncella } \\ & \text { de Nazaret, la más pura } \\ & \text { que se ha visto en estas tierras. } \\ & \text { ¡Qué chiquitín tan hermoso!... } \\ & \text { Toma mi mejor oveja, } \\ & \text { y si bala y te incomoda, } \\ & \text { zas, le cortas la cabeza. (28) }\end{array}$

La obra se cierra con una última escena en que los pastores hacen huir a Luzbel, dándole palos ${ }^{57}$, y una danza en coro, con la que se cierra el telón. El tono amenazador y trágico del cruel Herodes, el estilo solemne y sabio del anciano Samuel, el lisonjero y altivo de Doris, contrasta con las tonterías bufonescas del pastor bobo. Sus intervenciones son islotes cómicos dentro del argumento de trasfondo trágico.

El pastor bobo de estas obras decimonónicas muestra el mismo carácter ambivalente que siglos atrás. No encarna solamente los vicios censurados (pereza, egoismo, falsedad, atrevimiento), sino también ciertos valores (ingenio, bondad, fidelidad, incluso arrojo y audacia al engañar al mismísimo Herodes, fingiendo estar borracho). No es este el lugar para profundizar en la comicidad del pastor en el teatro entre los siglos XV y XVII, a lo que se han dedicado notables estudios ${ }^{58}$. Pero sí es necesario recalcar que, en el teatro navideño decimonónico, al igual como ocurría en aquellas obras en las que se inspira, el pastor no solo es sujeto de comicidad pasiva, cuyas tonterías y ridiculeces provocan la carcajada a costa suya, sino también sujeto activo de la burla. El pastor de las farsas navideñas adopta las mismas características caricaturescas de la comedia profana: es dormilón, perezoso, dado a la comida y al vino, comportamientos todos que, más allá de los pecados de acidia y gula, sintonizan con la representación carnavalesca del cuerpo. Junto a las libertades corporales, están también las verbales, representadas en locuacidad, procacidad zafia, gusto por las porfías y los insultos, cierta irreverencia e incluso algunos toques de erotismo más o menos chabacano, como el tomar a la Virgen como moza que cortejar. Con esas características, el pastor muestra a veces el lado placentero de la vida, aun cuando sea bajo el prisma de lo grotesco. Como sujeto pasivo de la risa aparece como bobo, supersticioso, ignorante e inocente, capaz de creerse cualquier cosa. Cobarde o fanfarrón, el pastor provoca la risa a su costa. Pero en el transcurso de la obra, esos mismos bobos pueden tornarse ingeniosos hombres que burlan

57. Pastores: -«juera! jfuera!» (le dan de palos).

58. Véase nota 44 
el poder de los malvados. La estupidez y la astucia son las dos caras de un personaje ambiguo que desde el bobo pastoril clásico, pasará al bobo gracioso de los entremeses (tipo Juan Rana), hasta llegar a diferentes géneros populares en que aparece ora Juan el Tonto, ora Juan el Listo ${ }^{59}$.

\section{Didactismo y humor: Lo JOCOSERIO}

No hay duda del carácter didáctico-piadoso de estas obras religiosas navideñas, como tampoco que recurren a antiguas claves del humor pastoril. Un prodesse et delectare que en el teatro navideño tiene unas específicas características que se arrastran a través de los siglos. El castigo ejemplar al pecador es tópico recurrente en sermones, catecismos y obras piadosas de todos los siglos. El malvado será más dichoso al ser castigado -enseña Severino Boecio- no solo porque así puede corregirse, sino porque la pena es proporcional a su culpa, y la justicia les reporta algún bien ${ }^{60}$ La idea será repetida desde Santo Tomás hasta la actualidad, pasando por obras muchas veces reeditadas como el Precio de la Divina Gracia de Nieremberg (1636). Pero ese castigo puede infligirse de múltiples maneras, diversidad que ha plasmado la pintura, el ritual y el teatro, desde las escenas más cruentas de mujeres pecaminosas colgadas de sus pezones o inimaginables tormentos en el purgatorio, hasta la tradición que se ríe del diablo, ridiculizando incluso sus poderes o mostrándole como un bufón ${ }^{61}$.

No pocas veces, como es aquí el caso, ambas tradiciones -la horrible y la burlesca- se han entrelazado. Con la intención de disuadir a los pecadores, pero con la obligación de hacer el teatro deleitable, el diablo y los demonios pueden aparecer como personajes terribles («una cabeza monstruosa arrojando fuego por la boca», según consta en la didascalia de la zarzuela analizada), aunque sus comportamientos inciten más a la risa que al terror: como el «baile de diablos» de esta obra o la paliza que se propina a los dos judíos avaros. La naturaleza bifronte del mal -ora hay que temerle, ora no

59. Cazal, op. cit., p. 10.

60. «Los malos, cuando son castigados, tienen anejo algún bien, que es la pena que padecen, la cual es buena por razón de que es justicia; y en los mismos malos, cuando carecen de castigo, está algún otro mal de más a más, el cual es la privación de pena: por lo cual más desdichados son los pecadores cuando sin hacer justicia en ellos están privados de pena, que cuando con justo castigo son afligidos» (Lib. 4, Cons., cap. 12).

61. Véase T. Ferrer Valls, «Las dos caras del diablo en el teatro antiguo español», Actas del Congreso Diavoli e Mostri in Scena dal Medio Evo al Rinascimento, Roma, 1989; y J. P. Wickersham Crawford, «The Devil as a dramatic figure in the Spanish religious Drama before Lope de Vega», Romanic Review, I, 1910. 
hay que tomarle en serio, pues nada puede contra el bien- pervive, como vemos, en el teatro religioso de finales del siglo XIX. Si en el siglo XVI no solo en la dramaturgia ritual o la iconografía al estilo del Bosco, sino sobre todo en la literatura -en comedias, autos sacramentales, cuentecillos, novelas -se hace presente esta faceta risible al modo del Diablo cojuelo, en el XVIII y XIX la comedia de Magia abusará tanto de los temas diabólicos que logrará una auténtica banalización del diablo. Se produce así, como ha señalado Caro Baroja ${ }^{62}$, un relajamiento, como consecuencia del exceso de familiaridad del demonio, y de tanto texto que inspira la posibilidad de burlarse del demonio impunemente.

Fueron legión los autores -laicos y religiosos- que en la segunda mitad del siglo XIX escribieron este tipo de dramas religiosos para ser representados en Navidad o Reyes, y es generalizado tanto el ánimo educativo, como la vocación jocosa para divertir a través de diálogos dramáticos, comedias, zarzuelas y otros géneros que se prestaban a esa mezcolanza. Un último ejemplo será útil para comprender el ánimo didáctico y recreativo de estas obras. El jesuita extremeño Vicente Gómez-Bravo escribía Los ladrones de Belén en $1893^{63}$, para proporcionar «un rato de lectura o representación sencilla y piadosa, con que puedas amenizar en el seno de tu familia las tertulias de Navidad», deseando que «si mis poesías consiguieren divertirte santamente, siquiera por una noche, han cumplido con su objeto» ${ }^{64}$. Los personajes y las acciones burlescas, intercaladas entre las piadosas, no contradecían la diversión santa en Navidad. Tres son Los ladrones de Belén, que entablan un diálogo dramático en una cueva, en tiempos de la matanza de los Inocentes. Dimas y Gestas son el buen y el mal ladrón respectivamente, según la tradición apócrifa que puso nombres a los que acompañaron a Jesús en la Pasión. Mientras el primero, conmovido por su encuentro con María, San José y el Niño, se arrepiente y se vuelve bondadoso, el despiadado Gestas no duda en robar y asesinar sin escrúpulos a gentes indefensas: niños, mujeres, sin querer detenerse siquiera ante la Sagrada Familia. El tercer ladrón es un sevillano pícaro y guasón -Simón-, que con acento andaluz ${ }^{65}$ se jacta de sus fechorías,

62. J. Caro Baroja, Las formas complejas de la vida religiosa (Siglos XVI y XVII), Madrid, 1985, p. 90.

63. Recopilado después junto a otras poesías y obras dramáticas navideñas en V. GómezBravo, Noche-Buena en Familia. Poesías y diálogos propios de Navidad, segunda edición, Madrid, 1901. Por esta edición cito.

64. Op. cit., p. 6.

65. Y eso que Barbieri pensaba que «las andaluzadas iban de capa caída» (op. cit., p. 56). 
desde su primer timo hasta el birlarle al propio Herodes «catorse talentos» (18). Si Dimas se lamenta solemne, «en serio», como dice la didascalia, de la matanza de los Inocentes, el ladrón cómico da la réplica relejada:

$\begin{array}{ll}\text { Simón: } & \begin{array}{l}\text { Que el maldito de Herodes } \\ \text { jase un gazpacho é chiquiyos. }\end{array} \\ \text { Dimas: } & \text { ¡Cómo! ¿Los está matando? } \\ \text { Simón: } & \begin{array}{l}\text { Y sin dejar uno vivo: } \\ \text { a toitos los cachetea. } \\ \text { Se ha empeñao en que ha nasío } \\ \text { un nene que diz que aspira } \\ \text { a timarle el señorío, } \\ \end{array} \\ & \text { y pa que no se lo time } \\ & \text { se loiere enguyir vivo. (19) }\end{array}$

La narración jocosa que hace el apicarado ladrón andaluz de todos sus golpes conforman un anecdotario en clave de chascarrillos, cuya única intención es la de suscitar la risa. Como en ciertos pastores bobos, su comicidad es activa, es decir, el público se ríe con ellos, pues en el fondo muestra una picaresca ingeniosa simpática al espectador. Simón consigue beber vino de balde engańando a la posadera a la que da el cambiazo de una tinaja de agua, que él trae, para llevarse una de vino llena; se marcha sin pagar con sus camaradas, pues tras fingir todos que quieren pagar, convencen a la posadera para que ella misma, jugando a la gallina ciega, señale cogiendo a uno quien debe ser el agraciado, lo que aprovechan para coger las de Villadiego y desaparecer. Estas y otras ingeniosas tretas, unido al desparpajo y aun la bravuconería del andaluz, le convierten en un personaje gracioso, máxime cuando sin achicarse hace huir al malvado Gestas (43), amenazándole con su habitual lenguaje chusco.

$$
\begin{array}{ll}
\text { Simón: } \quad & \text { ¡Si espatarro el limpiadientes! } \\
& \text { (Saca la navaja) } \\
& \text { ¡Te engilo como á un borrego! } \\
& \ldots \text { (Gestas se escapa y sale precipitadamente) }
\end{array}
$$

Es el tipo desvergonzado, pero que al contacto con el Bien, se muestra sincero y presto a enmendarse. "Yo estoy medio conmovío... / en cuanto tenga dinero / he de hacer por convertirme» (41), dice en un último exhorto, con el cual se acaba la obra. Es Los ladrones de Belén pieza escrita para 
aficionados, que la representarían en funciones más o menos domésticas durante las Pascuas, pero hecha con las mismas hebras con que se escribían piezas de mayor calado, puestas en escena en las salas de teatro.

El autor dramático de finales del siglo XIX -fuera de zarzuelas, comedias o breves diálogos dramáticos- sabía que el público que asistía a sus obras navideñas esperaba la presencia de lo jocoso y cómico, y muy especialmente la mezcla sagrado-profana que era consustancial a estas obras desde antiguo. El mismo autor (José Felis) escribía comedias y zarzuelas de trasfondo piadoso en las que no se permitía estas licencias ${ }^{66}$, pero en las navideñas no olvida ni al pastor cómico ni las escenas en que los malvados reciben una buena tunda de palos. Naturalmente hay diferencias notables con respecto a las comedias navideñas de los siglos XV a XVII, que ya se han sugerido: el humor es menos atrevido, sin el lenguaje chocarrero que caracteriza a veces el sayagués; el pastor soez e irreverente, que incluso se burla de religiosos y teólogos, con quienes mantiene disparatados debates, se trasmuta en las obras decimonónicas en un tipo más atemperado, que si conserva el espíritu jocoso del bobo, es mucho menos deslenguado y satírico que el de las comedias clásicas. La vena erótica, escatológica y libertina, y en general las licencias burlescas para comentar dogmas cristianos, han desaparecido en gran medida. A finales del siglo XIX quedaba lejos la ambivalencia de las manifestaciones grotescas, la visión erasmista sobre la locura, y las prácticas festivas carnavalescas -que jugaban a ponerlo todo patas arriba entre Navidad y Reyes- se habían atenuado bastante en la ciudad, aunque pervivían en contextos rústicos. Fue, sobre todo, en los pueblos y las aldeas donde continuó representándose un tipo de teatro navideńo, centrado en la Adoración de los pastores, donde las bufonadas del pastor bobo, los palos, las fustigaciones y las licencias carnavaleras siguieron compaginándose con el sentido devoto del misterio navideño.

\section{El teAtro NAVIDEÑo BURLESCO DE MUJERES}

Ni fueron solo hombres, ni en exclusividad vinculados a la Iglesia (sacerdotes y frailes), los autores de dramas navideños jocoserios. Ya hemos citado el drama sacro de Enriqueta Lozano titulado Dios es el rey de los reyes, compuesto en 1852. La fiebre dramatúrgica de finales del siglo permitió que muchas más mujeres escribieran obras de teatro, en algunos casos de

66. Por ejemplo J. Felis, Verdadera manera de divertirse. Juguete cómico en un acto para niñas, música de D. Federico Vela, Valencia, 1905. Puede verse también J. Felis, La murmuración. Zarzuela en un acto, música de D. José Planas, Valencia, 1905. 
trasfondo moralista y religioso, habida cuenta del ámbito familiar y piadoso en las que sí se les permitía que se desenvolvieran. En 1893 da a la imprenta Adelaida Muñiz y Mas La huida a Egipto y El nacimiento del Hijo de Dios. Mercedes Velilla y Rodríguez publicaba en Barcelona una pieza corta ${ }_{j}$ Noche Buena! (1895). Y un año más tarde escribía Isabel Creix Martínez en Sevilla La adoración de los reyes (1896) para ser representada por niños. No faltaban monjas, algunas de ellas muy prolíficas, que publicaban comedias y diálogos navideños moralistas para ser puestos en escena bien por las propias religiosas, bien por niñas de colegios. Así, por ejemplo, Una Noche-Buena ${ }^{67}$, comedia de sor F. G. L. -así firma-, religiosa del convento de Dominicas de Santa Rosa de Zaragoza, publicada en Zaragoza en 1890.

A pesar del signo conservador y tradicionalista con que está escrita la mayoría de estas piezas navideñas, casi nunca falta el elemento costumbrista y pocas veces la comicidad explícita. Es el caso - por profundizar en un solo ejemplo- de Adelaida Muñiz y Mas, autora de más de una docena de obras dramáticas que se publicaron y representaron en Madrid entre los años 1892 y 1898. Entre ellas hay dramas de honor (Mancha heredada), comedias paródicas y satíricas contra la clase media (La herencia de Tenorio), teatro social (El pilluelo de Madrid o Los hijos del pueblo), arengas patrióticas (Roja y gualda), monólogos dramáticos (Ilusión y desengaño) y dramas sacros navideños, lo que es significativo para comprender la variedad de géneros a los que estaban acostumbrados los autores de dramas religiosos navideños. El nacimiento del Hijo de Dios o La adoración de los Santos Reyes, escrita en colaboración con José de la Cuesta y música de T. F. Grajal, fue representada en el Teatro del Príncipe Alfonso una Nochebuena de 1892, y se publicó poco después. La espectacular puesta en escena, con un reparto numeroso y un vestuario lujoso ${ }^{68}$, era muy esperada por el público, que asumía la extraordinariedad del evento. La obra de Muñiz tiene todos los ingredientes del drama religioso navideño: multitud de escenas que se suceden vertiginosamente hasta un número de 53 , situaciones y diálogos cómicos, peleas entre los pastores, protagonismo del pastor bobo o gracioso, diablos cantarines y aun escenas audaces, como la protagonizada por Bato, el pastor rico y odioso, que se pregunta si María estará enamorada de él, a lo

67. Ésta está ambientada en un castillo feudal de Aragón durante la noche de Navidad de 1096. Es comedia en un prólogo, tres actos y cinco cuadros y en verso (F. G. L., op. cit.).

68. El arcángel Gabriel -según dice la propia autora- debía llevar mallas de carne, calzadillo blanco, de lujo, peto y faldetas blancos, con adornos dorados, alas blancas, cintillo dorado y un cinturón blanco y dorado (A. Muñiz, El nacimiento del hijo de Dios, Madrid, 1893, p. 8.). 
que su amigo Julepe responde: «Ya verás tú cómo cambia / cuando tu vara florezca» $(\mathrm{I}, \mathrm{iv}, 1)^{69}$.

En definitiva, si el trasfondo devoto y familiar propiciaba que las mujeres -laicas y religiosas - escribieran y vieran representar sus dramas navideños, las licencias cómicas de la Pascua, que se habían convertido ya en constitutivas del género teatral en esas fechas, permitían el uso más o menos convencional de un humor no por estereotipado menos esperado por el público.

\section{TEATRO POPULAR Y FESTIVO}

No solo en las salas de teatro se representaban piezas navideñas: también en la calle, en las casas particulares, en las iglesias. Se llaman pastoradas o corderadas a los autos navideńos populares, generalmente de un solo acto, representados en las iglesias en Nochebuena, con un texto dialogado en que se desarrolla el motivo de la Anunciación ante los pastores, las dudas de éstos y su posterior viaje a Belén para ofrecer la cordera y otros presentes. Aunque siguen los tópicos del teatro navideño de los siglos XV a XVII, la mayoría de las pastoradas conservadas hoy son de siglos posteriores (entre los siglos XVII y XIX). De algunas conocemos incluso su autor. Es el caso, por ejemplo, de las dos pastoradas del poeta rural leonés Julián Escudero (18151898), natural de Audanzas del Valle, en el partido judicial de la Bañeza ${ }^{70}$. El cotejo de estas obras demuestra que pastoradas, zarzuelas, diálogos, comedias navideñas repiten los motivos jocoserios y hubieron de influirse mutuamente en un tiempo de desarrollo tanto del teatro profesional, como del aficionado. Los celos de San José, el pastor dormilón e incrédulo que prefiere seguir durmiendo después de la Anunciación del ángel o el que solamente piensa en llenar el estómago son solo algunos ejemplos de episodios y arquetipos, repetidos en los diferentes géneros decimonónicos, y en los que -como en los autos más clásicos- cabía al mismo tiempo un mensaje adoctrinador y el solaz de los espectadores. Si el mayoral de Juan del Encina reprende la obsesión pantagruélica del pastor ( No penséis ahitaros / que no es cosa de comer»), los pastores de las corderadas siempre quieren «hacer unas migajuelas / bien componidas con sebo» ${ }^{71}$, tópico que aparece también en villancicos cultos como los de Rodrigo de Reinosa («más vale que comer

69. Véase D. T. Gies, El Teatro en la España del siglo XIX, Cambridge, 1996, p. 304.

70. J. Díaz, J. L. Alonso, Autos de Navidad en León y Castilla, León, 1983, p. 67.

71. Corderada de Villabraz (Díaz, Alonso, op. cit., p. 31). 
migas / ver cantar unos garçones...» ${ }^{72}$, o en las zarzuelas y comedias que hemos analizado páginas atrás. Si en la zarzuela El nacimiento del Niño Dios, el pastor bobo se contrapone al sabio mayoral Roboám, en las pastoradas es igualmente frecuente que el mayoral (también llamado Rabadán) sea el hombre bueno, al que se le aparece el ángel cuando guarda el rebaño, en contraposición al zagal (Zagalín, Zagaleto, Zagalejo), el chico de los recados, obligado a hacer las migas aunque no las coma, pero también el que asume el papel contestatario, burlón: «Déjame dormir, Rabadán, / déjame de chichiribeos ${ }^{73}$. Éste se funde muchas veces con otros pastores burlescos, de larga raigambre navideña: Pascual, Blas, Antón o Juan Lorenzo ${ }^{74}$, sin que falten apelativos chuscos como Macarrón, que recuerda al socarrón y aun al zaharrón, personaje carnavalesco que aún hace de las suyas en muchas fiestas invernales hoy en día. Como en las zarzuelas navideñas analizadas, ellos son los auténticos protagonistas. La Virgen, San José, las zagalas, incluso un cura que a veces era representado por el propio sacerdote en la iglesia, son personajes secundarios.

La alternancia de episodios, escenas y personajes serios, solemnes, sagrados, con los burlescos es el santo y seña del teatro religioso navideńo. La estructura fija la da la conocida secuencia de Anunciación, dudas de los pastores y final Adoración. El elemento sorpresivo radica en la subversión del zagal, así como en las sandeces ridículas del resto de pastores. La gracia de la obra se basa en la alternancia de momentos o cuadros solemnes, piadosos, en que prima el orden y la devoción, con otros basados en los diálogos chusqueros, las bromas y la risa que provocan la zafiedad y rudeza de los pastores. Es la misma lógica que rige en las zarzuelas y las comedias navideñas analizadas. En la pastorada que se interpreta en Laguna de Negrillos - por centrarme en un ejemplo-, aparte de que el Zagal se burle de las espantojadas del Mayoral y le moteje de «majadero», "cabeza de apóstol» o "engaña pastores», en sus maldicencias incluye localismos que a buen seguro arrastran a los espectadores: «Hasta me dan ganas de sacudirte un cachazo, porque tengo

72. J. M. Cabrales Arteaga, La poesía de Rodrigo de Reinosa, Santander, 1980, p. 137.

73. Corderada de Valverde (Díaz, Alonso, op. cit. p. 31).

74. El nombre de muchos de los protagonistas de los villancicos y los autos navideńos sugerían ya al público su carácter cómico, igual que el Padre Isla da satíricamente nombres de semántica jocosa para burlarse de los eruditos locales de la provincia de Campos en León, entre los que cita a Antón Borrego, Blas Chamorro, Domingo Ovejero y Pascual Cebollón, uniendo a los nombres connotados con la tontería, apellidos que remiten al mundo pastoril y campesino (J. F. de Isla, Fray Gerundio de Campazas, alias Zotes, edición de Enrique Rodríguez Cepeda, Madrid, 1995, p. 236). 
peor genio que la oveja del tío Pericote» (Díaz y Alonso, 1983: 98). Tal es el genio también del andaluz bravucón en Los ladrones de Belén, que no se achica ante el malvado Gestas ${ }^{75}$ :

Simón: Si das un paso adelante no respondo é tu pellejo, pardiez, que de un puñetazo te destampano los sesos! ¡Por vida é la sota é bastos!

Si los protagonistas de la misma pastorada de Laguna de Negrillos motejan a los taberneros de aguar el vino, a la par que se ensalza a los mesoneros que "parlan poco y hacen mucho", el escarnio de los taberneros estafadores es tópico que se vuelve a repetir en la zarzuela La Adoración de los Santos Reyes, donde el bobo Gedeón sugiere a Herodes que ahorque a los taberneros que «venden el vino aguado». El dormir, comer y beber, el holgar en general, incluso el jugar, cantar y danzar se contrapone siempre a la espiritualidad del misterio navideńo:

Tienes razón, Juan Lorenzo, pues, como dice el adagio, "de la panza sale la danza"; después de comer y beber bien ya podemos echar una bailá al niño en llegando allá en Belén ${ }^{76}$.

Ahí surge la risa navideńa: en el contraste entre las necesidades y pasiones mundanas, profanas - nunca colmadas entre campesinos, pastores y otros miembros de las clases populares- y la obligatoriedad de la devoción, la exaltación inmaterial, el dejarlo todo para adorar al Niño. Con botas de vino y escudrińando el zurrón entran en la iglesia los pastores de estos autos navideños populares ${ }^{77}$, y en algunas pastoradas, incluso en el ofrecimiento al Niño dan un botello de «buen vino que alegra el cerebro» ${ }^{78}$. Contraste frente a la devoción pía del resto de personajes, al igual que el simplón Batillo de Los pastores de la Judea ha de decir su broma boba mientras ofrece al Niño un cordero $^{79}$. En ocasiones, la final reconducción del pastor irreverente desvela

75. Gómez Bravo, op. cit., p. 42.

76. Auto de Pastores de Villamarco (Díaz, Alonso, op. cit., p. 158).

77. Auto de Pastores de Rucayo (Díaz y Alonso, op. cit., p. 166).

78. Auto de Pastores de Terradillos de Templarios (Díaz y Alonso, op. cit., p. 151).

79. Gras y Elías, op. cit., p. 28. 
el carácter pedagógico de la obra. Y sin embargo es igualmente frecuente el entretenimiento y la carcajada buscada descaradamente, sin otra razón que la del puro recreo en unas fechas propicias para algún tipo de licencias con lo sagrado.

Aún hay otros tópicos, que no hay lugar aquí para comentar, los cuales se repiten en autos pastoriles, comedias navideñas, diálogos, zarzuelas y otros juguetes cómicos. Así la burla misógina y las disputas entre sexos, que jalonan por ejemplo la zarzuela El nacimiento del Niño Dios, de José Felis ${ }^{80}$. Como tampoco faltan en las propias pastoradas representadas en las iglesias los palos y las fustigaciones, escarnio que reciben no ya los personajes de la obra que encarnan el Mal, sino los propios espectadores, especialmente las mujeres presentes ${ }^{81}$. Esta diversión carnavalera -la de dar palos, correr para no recibir o simplemente ver cómo otros lo hacen- era escenificada en el siglo XIX por el teatro navideño, con el mismo sentido híbrido entre la intención ritual de espantar el mal y el mero regocijo por comportamientos alborotadores, que el que aún pervive en ciertas fiestas y rituales navideños, en que las fustigaciones y cascaborrazos que dan y a la vez reciben ciertos personajes grotescos y risibles, son la sal y pimienta con que se despide el año ${ }^{82}$.

A medio camino entre el teatro, el ritual y la fiesta, están también algunos diálogos escenificados por parte de cuadrillas itinerantes que salían -y aún lo hacen en algunos lugares- pidiendo el aguinaldo por las casas. Es el caso del llamado Retablo de los Ángeles de Obejo (Córdoba), recuperado en el pueblo hace algunos años, y que estaba extendido en otros pueblos en el siglo XIX. Allí cada Nochebuena una comitiva formada por dos ángeles, San

80. En el tercer acto, el pastor Elicier se burla de las pastoras, explicando que el César romano está pidiendo los nombres de las mujeres "para cortarles la lengua / por habladoras", a lo cual replica Rebeca que éstas se ven obligadas a hablar tanto cuando ven «que están de brazos cruzados / o gimen cual mujercillas, / los pastores esforzados, / al verse ante los soldados / que saquean nuestras villas».

81. Así finaliza, por poner un solo ejemplo, la discusión entre el zagal y el mayoral del auto de pastores de Ribera de la Polvorosa: «Zagal: - ¿Qué comida traes aquí? / Yo nada puedo encontrar; / lo que tú te has llenado la panza / y a mí me has hecho ayunar (rompe el puchero). Mayoral: -¿̨or qué rompiste el puchero? / Los cascos, vela aquí están; / Dáme pronto de la bota / y márchate para atrás. // Mujeres, después de estar advertidas / de los años anteriores / nada saco en consecuencia, / cada vez me sois peores. // Míralas cómo se mueven, / mira qué quietas están; / si no hacéis caso del cayado / os daré con el fardel / aunque se me arrame el caldo ( $Y$ empieza a dar fardelazos)».

82. Los cascaborras e inocentes de Puebla de Don Fadrique (Granada) son un buen ejemplo (A. del Campo Tejedor, «Hacer el loco. Muerte, miedo y subversión en torno a la Navidad», VI Jornadas de Protección del Patrimonio Histórico de Écija, Écija, 2008). 
Gabriel, San Miguel, Lucifer y un mochilero, anuncia de puerta en puerta y representa en el interior de las casas un breve diálogo con el asunto de la Anunciación del Nacimiento por parte de dos ángeles y la lucha entre el diablo y los dos arcángeles. Como en las piezas decimonónicas representadas en las salas de teatro que hemos visto, aquí no falta ni Lucifer, vestido con pieles, cornamenta y arrastrando cadenas, ni la intervención del personaje gracioso: el mochilero, que alforja al hombro, pide los donativos en forma de dinero, viandas o vino, necesario para llegar hasta el portal de Belén ${ }^{83}$.

Existieron aún otras formas parateatrales navideñas, cuya relación con el teatro religioso navideño no es posible tratar aquí: títeres, teatrillos mecánicos y de figuras, como los que se instalaron en Madrid durante la Navidad de 1846, que no diferirían mucho de los más conocidos como el Belem de Tirisiti de Alcoy o La Tía Norica en Cádiz ${ }^{84}$, en los que se mezclaban las escenas religiosas, el costumbrismo y el humor.

\section{TIEMPO DE BURLAS: LA NAVIDAD DECIMONÓNICA, CONTEXTO DEL TEATRO JOCOSERIO}

Se quejaba el autor de una Crónica de Navidad publicada un 22 de diciembre de 1900 en La Ilustración Española y Americana que las de hacía un siglo (en 1800) eran "más ruidosas» habida cuenta de que «si la población ha crecido en doble y mitad, faltan casi todas las comunidades de frailes y se han derribado ó convertido en edificios públicos sus conventos» ${ }^{85}$. Después de lamentar la extinción de los conventos de las diferentes órdenes, exclama: «Calcúlese cuántas misas del gallo se celebrarían en Madrid!» ${ }^{86}$. Efectivamente, a finales del siglo XIX había pasado la época en que los conventos e iglesias de las grandes ciudades albergaban representaciones teatrales, villancicos, diálogos dramáticos, en los que se mezclaba lo jocoso con lo solemne. Estos divertimentos navideños, que merecieron incluso en ocasiones la persecución

83. «Buenas noches caballeros. / Entre Miguel y Parranda / han tenido buena historia. / Mas, pronto llegó Miguel / y se llevó la victoria. / Yo también quisiera llevarme / para mis compañeros limosna: / estas alforjas llenas de pan, / lomo, chorizo, jamón... / y dinero sin contar; / y esta bota llena de vino / para pasar el camino / hasta llegar al portal / donde nació el Rey Divino.»

84. Véase F. Porras, Titelles. Teatro popular, Madrid, 1981; y C. L. Aladro, La Tía Norica de Cádiz, Madrid, 1976.

85. Anónimo, "Crónica de Navidad», La Ilustración Española y Americana, año XLIV, núm. 47, Madrid, 22 dic. 1900, p. 357.

86. Ibidem. 
de la propia Inquisición ${ }^{87}$, tuvieron su apogeo en el siglo XVII, donde la burla ingeniosa y la mezcolanza sagrado-profana constituyó una auténtica moda en ciertos géneros literarios. Semejante registro perduró en muchas representaciones teatrales religiosas hasta el XVIII, donde los personajes que interpretaban a los zagales y los pastores protagonizaban escenas risibles para que -como dice uno de estos villancicos- «un juego se forme / de chistes vulgares, / que en trage de burlas, / misterios enlazen» ${ }^{88}$. Bastará citar aquí las diatribas de José Mariano Beristain, para comprender la pervivencia de la tradición parateatral de los villancicos burlescos a finales del XVIII:

¿Y cómo estamos nosotros en el año de 1787 uno de los más ilustrados o luminosos de nuestro siglo? ¿Hemos desterrado de nuestro Parnaso aquella chusma de versificadores bufones que inducían en el templo de Dios de majestad inefable los profanos conceptos y chistes insulsos que los gentiles no hubieran oído sin ira en los Fanos torpes de sus inmundas deidades? ¿Cómo celebramos hoy la Encarnación y el Nacimiento admirables del Hijo de Dios vivo? ¿Todavía halla nuestra consideración devota en el portal glorioso de Belén al tosco y grosero Pascual, al malicioso y juglar Bato, al atrevido y desvergonzado Antón? ¡ Ha! Allí están llenando de estiércol las pajas limpias donde está reclinado el Nińo Jesús, atormentando los castos y delicados oídos de su Purísima Madre y del casto esposo Joseph; e irritando a las bestias del establo, que obsequian con su silencio a aquellos Santos huéspedes más dignamente que los pastores charlatanes con sus coplas ${ }^{89}$.

No hablaba el autor del Diario Pinciano de las fiestas de locos medievales, sino de los villancicos que se seguían demandando en su época:

Diré lo que he visto. Se han impreso en esta ciudad tres juegos de villancicos para la Nochebuena de este año. Los unos para la catedral de Osma, los otros para la de León, y los últimos para la de Valladolid. Hay en ellos buenas cosas, no hay duda; pero las hay también de aquellas que el mencionado Feijóo llama compuestas al genio burlesco, como si las cosas de Dios fuesen de Entremés.

87. La Inquisición intervino en 1663, motivado por los villancicos, al parecer indecorosos, que cantaban las monjas de la Capilla Real de las Descalzas. El documento inquisitorial denuncia que tales prácticas son especialmente frecuentes en los conventos de religiosas y durante las fiestas de Navidad y Reyes. Paz y Melia (Sales españolas o Agudezas del ingenio nacional, Madrid, 1964, p. x-xi) reproduce parcialmente el citado auto inquisitorial.

88. Villancico cantado en la iglesia de Toledo en 1708 (C. Bravo-Villasante, Villancicos del siglo XVII y XVIII, Madrid, 1978, p. 206).

89. J. M. Beristain, Diario Pinciano, reproducción facsímil, Valladolid, 1978, p. 472. 
Un titilimundi en los hombros de un francés, a quien saludan los pastores con los decentes y urbanos nombres de animal y pollino, se habrá representado en el coro de la catedral de Osma... ${ }^{90}$

Años después de las censuras de la Inquisición, se seguían representando titilimundis y diálogos de pastores burlescos, con nombres arquetípicos -Antón, Pascual- que el pueblo enseguida reconocía. Con todo, durante los siglos XVIII y XIX el gerundismo festivo fue perdiendo fuelle al mismo ritmo que la Iglesia lo veía resquebrajarse ante el civilismo ilustrado, máxime después de la exclaustración, hito que modificó sustancialmentelas costumbres religiosas populares especialmente en las ciudades. Mientras en las grandes urbes las iglesias fueron dejando poco a poco unas representaciones con secular fama de chocarreras, en los pueblos pervivieron los autos navideńos, los diálogos escenificados, los sainetes y otras piezas. En gran medida las salas de teatro absorbieron aquellas antiguas funciones cómicas en las iglesias. Si el ambiente risible no había cesado en las calles y plazas de las grandes ciudades, no es de extrañar que el teatro navideño jocoso no se extinguiera: más bien se recondujo parcialmente hacia espacios profanos, una vez la Iglesia perdió la capacidad y el interés en llevar la batuta de estas escenificaciones ambiguas. Y es que la concepción según la cual la Navidad abría un período de licencias que en algunos casos no se concluía hasta el Carnaval, perduró a lo largo de todo el siglo XIX. Sobre todo en las provincias y en ambientes rústicos hay innumerables ejemplos etnográficos que así lo avalan. Se hacen eco de ello las novelas costumbristas ${ }^{91}$, los relatos de viajeros extranjeros ${ }^{92} \mathrm{o}$ los artículos periodísticos de algunos folcloristas, como Benito Más y Prat ${ }^{93}$. Las parrandas y mascaradas de Pascua no se circunscribían solo a los rústicos,

90. Op. cit., p. 472.

91. En La Noche de Navidad, incluida en Escenas Montañesas (1864), José Ma de Pereda recrea con bastante realismo las diversiones burlescas de los marzantes, un grupo de aguilanderos que recorren las casas armando alboroto y cantando coplas elogiosas si son recompensados en su recuesta, o de escarnio si no obtienen lo deseado (J. Ma . de Pereda, Escenas montañesas, Madrid, 1975).

92. El reverendo James Meyrick cuenta a mediados del siglo XIX las bromas que acostumbraban a gastar los malagueños en el día de los Inocentes, por ejemplo pedir prestado dinero a alguien con mala memoria - para que lo olvidara- así como prometérselo pagar «el próximo año, el mismo día, es decir, cuando las calendas griegas, nunca» (F. Meyrick, Cartas desde Andalucía. Estancia en Málaga y viaje por Andalucia, Málaga, 2000, p. 44).

93. Éste cuenta en 1885 cómo en Écija (Sevilla), durante el día de los Inocentes salían los locos, un grupo de danzantes carnavaleros, auspiciado por la hermandad de las ánimas, bailando y cantando repetitivamente "a la danza de los locos / a la danza de los locos», costumbre que aún perdura hoy en alguna pedanía como Fuente Carretero (A. del Campo, op. cit., 2008). 
sino que también se daban en pleno centro de Madrid. La descripción que hace el poeta Martínez Villergas en una miscelánea que salió en 1847 bajo el título de Album de Momo, es sintomática de una época que se debate entre el costumbrismo romántico y el desdén postilustrado para con las prácticas festivas populares.

Efectivamente, hay en Madrid, en el pueblo más culto de España, costumbres tan ridículas y chocarreras que harían poco favor a la aldea más miserable y atrasada. Una de las escenas grotescas que no ha podido destruir la ilustración es la que se ofrece en la llamada noche de Reyes. Vayan ustedes a la Puerta del Sol y verán lo que es bueno y barato; desde lejos se siente un gran ruido de cencerros y zambombas que parece que va a pasar una procesión de demonios, y lo que pasa es un gallego cargado con una enorme escalera, acompañado por una multitud de granujas que le van alumbrando con sendas hachas de viento. Otros le dan una música infernal de cencerros, y trayendo y llevando al inocente que lleva la carga de aquí para allá y de allá para acá, atraviesan la población en medio de las carcajadas y silbidos de la multitud $^{94}$.

La descripción de Villergas se acompańa de un grabado que ilustra la escena: una auténtica turba de hombres enmascarados arropan al inocente que, escalera en mano, va precedido de un personaje con enormes orejas de burro, zamarra de pieles, un cencerro en la mano derecha y un hachón en la izquierda. Entre la multitud los hay que blanden o tocan unos enormes cuernos, y todos parecen gritar o cantar agitadamente. Mesonero Romanos también dedicó unas líneas a esta costumbre, lamentando la inocentada que se gastaba a los «pobres asturianos o gallegos recién venidos, cuya supuesta ignorancia les hace servir de juguete a los pilluelos de la corte, bajo el pretexto de llevarlos a esperar a los Reyes Magos» ${ }^{95}$. Él mismo sugería al Gobierno en 1852 que prohibiera aquella "turba vocinglera de los embromadores", el espectáculo de los «mozallones ridículamente ataviados con esteras y coronas» que irrumpían «dando aullidos, saltos y cabriolas». Y verdaderamente a lo largo de la segunda mitad del siglo XIX, estas costumbres quedarán confinadas poco a poco en los pueblos y aldeas, especialmente del norte de la Península. De hecho, según otra descripción de $1884^{96}$, aquella procesión burlesca de Reyes había decaído bastante.

94. J. M. Villergas, «Los reyes», Album de Momo, Madrid, 1847, p. 464-465.

95. R. Mesonero Romanos, Tipos y caracteres, Madrid, 1881, p. 211-212.

96. E. de Olavarría y Huarte, «El Folk-lore de Madrid», Biblioteca de las Tradiciones Populares Españolas, II, 1884, p. 90-95. 
Censuradas por la Iglesia y por el Estado -que prohibía incluso las serenatas navideñas en la calle- el espíritu de muchas de estas manifestaciones ruidosas fue reconducido a las salas de teatro, especialmente en las ciudades, donde quedaron como el lugar donde escenificar la alegría un tanto disparatada propia de esas fechas. Es en este contexto, en el que cabe comprender la burla en los espectáculos teatrales navideños, en algunos de los cuales llegaron a actuar los mismos artistas que cobraban protagonismo en la calle durante las fiestas de Navidad ${ }^{97}$. De la interrelación y los préstamos mutuos entre el teatro navideño representado en las salas y las costumbres lúdico-festivas callejeras, así como de la tendencia a adaptar estas representaciones al gusto local, da fe la "Advertencia» que publica el autor de la «Breve representación dramática» titulada Los Pastores de Belén, escrita a mediados del siglo XIX, y muchas veces reeditada. En su cuarta edición, en 1902, escribe:

Poco añadiremos á la anterior advertencia puesta al frente de la primera edición en 1847: que la idea de la segunda escena, que mediante una aparición anticipada permite hacer hablar al Dios Niño, es debida á una canción popular ${ }^{98}$ muy repetida por Madrid en Noche Buena; que el autor no sale responsable de las modificaciones más ó menos oportunas, ensayadas ó que se ensayen en su obra al representarla, ni tampoco las rechaza en principio $^{99}$.

\section{LA RECEPCIÓN DEL TEATRO NAVIDEÑO BURLESCO}

Este contexto temporal de alegría y cierta permisividad explica algunos rasgos tanto de la creación de estos textos jocoserios, como de su recepción entre los espectadores. Las funciones en las fiestas de Pascua tenían que estar dirigidas a divertir, cuando no a provocar la carcajada. A la representación de una zarzuela, por ejemplo, podía seguirle «un fin de fiesta propio de los días de Pascua» ${ }^{100}$, como anunciaba un periódico pacense con respecto a

97. Por la misma época en que Benito Más y Prat escribía sobre la importancia del pandero en la misa del gallo y otras momentos festivos, algún virtuoso panderetero era contratado para actuar en el teatro, cual es el caso de un tal Tomás López, que «no sólo lució su portentosa agilidad en la pandereta, sino que auxiliado por su hija hizo otras habilidades» (La Crónica, 18 de enero de 1874, apud Suárez, 1995: 616).

98. Ésta no es otra que el conocido villancico: «Madre, a la puerta hay un niño / Más hermoso que el sol bello, / Que está llorando de frío, / Y el pobrecito va en cueros» (J. M. Q., Los Pastores de Belén. Breve Representación Dramática, Palma, 1902, p. 10).

99. Op. cit., p. 4.

100. Suárez, op. cit., p. 483. 
la función del 26 de diciembre de 1883. El propio Barbieri, recordando el estreno de una zarzuela suya ${ }^{101}$ en la noche del 24 de diciembre de 1853 , en el Teatro del Circo, se sorprendía de que «el público oyó esta obra con una seriedad extraordinaria en semejantes días» ${ }^{102}$. No hay que pensar en un público disciplinado, como el que asiste hoy a los teatros, sino más bien lo contrario: silbaba, gritaba o aplaudía ruidosamente, cuando no mandaba repetir algunos pasajes o se permitía vocear alguna frase intercalándola en la obra.

El domingo 24 de diciembre de 1854 se estrenó La cola del diablo ${ }^{103}$, que hizo mucha gracia y dio buen número de representaciones en la temporada. La canción francesa del $2^{\circ}$ acto, la arreglé yo para orquesta por una de piano. En las representaciones de esta obra se divertía mucho el público, y lo tomaba tan a broma que hacía repetir la escena en el segundo acto, en que don Martín de Torreones da de culadas a sus dos interlocutores sobre las sillas. También se repetía 3 y 4 veces la canción francesa ${ }^{104}$.

Significativa es la carta que recibía Barbieri de su madre, estando él en París, en la que aquella le tenía informado de la última zarzuela estrenada el 23 de diciembre de 1860, El gran bandido: «Aunque es un sainetón tiene gracia, y la gente se tendió de risa con Caltańazor y Arderius. [...] Decía la gente que ésta era la obra de Pascuas en que se debe reír, y no llorar como en La hija del pueblo» ${ }^{105}$. La hija del pueblo ${ }^{106}$ era una zarzuela, estrenada el día anterior ( 22 de diciembre), que no gustó al público, el cual la censuró con «buenos silbidos», no tanto - dice la madre de Barbieri en otra carta- "porque sea buena o mala, sino por lo decantada y ponderada tanto tiempo» ${ }^{107}$. Por

101.Galanteos en Venecia, que -como él mismo reconoce- tuvo una discreta recepción.

102. Barbieri, op. cit., p. 108.

103. Zarzuela en dos actos de Cristóbal Oudrid y Martín Sánchez Allú; libreto de Luis Olana.

104. Barbieri op. cit., p. 124. Hay muchos otros testimonios en la misma línea. Cuenta Barbieri que El diablo en el poder, zarzuela con muchas alusiones políticas, fue censurada poco después de estrenarse en diciembre de 1856, principalmente por un coro, cuya letra decía: «hay crisis!», lo que gustaba mucho al público, que mandaba repetirlo. El gobernador de Madrid mandó suprimir dicho coro y modificar sus versos, para que la obra pudiera seguir representándose, pero el público que ya tenía noticia de lo ocurrido, mandaba sin embargo repetir esta pieza y siempre que los coristas decían ; hay algo!, la gente contestaba crisis (Barbieri, op. cit., p. 179).

105. Barbieri, op. cit., p. 310.

106. Zarzuela en dos actos de Emilio Álvarez.

107. Barbieri, op. cit., p. 308. 
el contrario, El gran bandido, representada el 23 de diciembre, era «una obra destinada a hacer reír y lo consigue», como la enjuicia un periódico de la época, destacando el aplauso del público por «los chistes y equívocos en que abunda" ${ }^{108}$. Por aquel entonces, en los días anteriores y posteriores a la Navidad se estrenaba cada día una zarzuela que, a tenor de las crónicas periodísticas, gustaban cuando entretenían y hacían reír ${ }^{109}$. Así se explica el éxito de las obras estrenadas en Navidad desde las primeras décadas del Teatro de la Zarzuela. «Sin ninguna pretensión el 21 [de diciembre de 1867] se estrena Los caballeros de la tortuga, zarzuela en tres actos de Eusebio Blasco y música de Gaztambide que hicieron una obra típica de Pascuas, parodiando situaciones culminantes de dramas conocidos, que resultó, más que zarzuela, género bufo»" ${ }^{110}$, escribe Emilio García Carretero, el cronista del Teatro de la Zarzuela, basándose en las crónicas periodísticas de la época. Dos años más tarde, «la víspera de Nochebuena [1869] por la tarde se estrena la típica obra de pascuas que logra plenamente el objetivo para el que fue escrita: hacer reír a los espectadores» ${ }^{111}$. La prensa de la época es testimonio del gusto popular por las obras navideñas que diviertan. Los periódicos de la capital rindieron todo tipo de elogios en el estreno un 21 de diciembre de 1870 de la zarzuela El molinero de Subiza ${ }^{112}$, con la sola pega de haberse dado a conocer en Navidades, «fechas en las que los espectadores prefieren obras más cómicas» ${ }^{113}$.

Ese tiempo de licencia, que se vivía por igual en la calle como en el teatro, se cerraba al finalizar el Carnaval. En los meses de enero, febrero y marzo -dependiendo de los años- hasta el comienzo de la Cuaresma, se daban durante varios días en el Teatro de la Zarzuela bailes de máscaras. Incluso en algunas ocasiones (así, por ejemplo, en febrero de 1858) los propios miembros de la compañía, convertidos en comparsa carnavalesca, salían a la calle cantando, para atraer al público ${ }^{114}$. Había así cierta continuidad en el clima carnavalero teatral desde Navidad hasta Carnestolendas, como

108. Barbieri, op. cit., p. 309.

109. Véase Barbieri, op. cit., p. 310-311; 334.

110. E. García Carretero, Historia del Teatro de la Zarzuela de Madrid, tomo primero: 1856-1909, Madrid, 2003, p. 62.

111. García Carretero, op. cit., p. 72. Y por el contrario: «La tarde del 24 [de diciembre de 1868] Los envidiosos, comedia en tres actos de Pantaleón Moreno Gil que resultó demasiado seria para un día de Nochebuena» (op. cit. p. 67).

112. Zarzuela en tres actos de Luis Eguilaz y partitura de Cristóbal Oudrid. Del éxito de esta zarzuela habla el que se haya representado incluso recientemente, durante el año 2008, en el teatro municipal Francisco Rabal (Pinto, Madrid).

113. García Carretero, op. cit., p. 72.

114. García Carretero, op. cit., p. 14. 
demuestra el hecho de que en algunos años (como en la temporada 186061) el primer baile de máscara tuviera lugar en Noche Vieja, justo a las 12 de la noche. Y no era infrecuente la temporada en que la misma semana en que se despedía a las Pascuas con la noche de Reyes, se iniciaran los bailes de máscaras ${ }^{115}$.

No ocurría otra cosa en las provincias. En Pontevedra, por ejemplo, la Sociedad Carnavalesca de la ciudad firmó un contrato en 1888 con el cuadro de zarzuela que actuaba en el teatro del Liceo con el objeto de organizar algunos espectáculos y conseguir fondos para las mascaradas que saldrían en Carnestolendas ${ }^{116}$. Y en todas las provincias las Pascuas llenaban los liceos y teatros de obras cómica. ¿Cuál era la función, por ejemplo, en una Navidad de 1872 en el Teatro del Campo de San Juan (Badajoz)?: La zarzuela de Luis de Olana con título Al fin casé a mi hija, la conocida zarzuela bufa de Eusebio Blasco El joven Telémaco, y el sainete Turris burris ${ }^{117}$. El tono ligero, risible, incluso grotesco, de esta función triple, era idóneo para el día de Navidad. Recuérdese la célebre canción de El joven Telémaco («me gustan todas, me gustan todas, / me gustan todas en general...») o el coro en griego macarrónico:

\section{Suri panta, la suri panta Macatruqui de somatén Sun fáribun, sun faribén Maca trúpiten sangarinén.}

Sobre Los aguinaldos, dice un crítico pacense, que "tuvo un éxito satisfactorio merced a los chistes de que está salpicada» (La Crónica, 3 de enero de 1873) ${ }^{118}$. En este contexto hay que situar la representación de obras navideñas costumbristas y sobre todo de las comedias, dramas y zarzuelas sacras que aquí hemos analizado. El ambiente jocoso de la Navidad permitía -y el público demandaba- la representación tanto de las comedias de equívocos, los Bufos desvergonzados ${ }^{119}$, como del misterio navideño con aires cómicos, propios de este singular teatro religioso que rememoraba los antiguos autos. Un último ejemplo es paradigmático de la mezcla de jocosidad y religiosidad con que se iba al teatro en Navidad. En los teatros

115. Por ejemplo en el año 1864 los bailes de máscaras tuvieron lugar los días 9, 16, 23 y 30 de enero, y 9 y 14 de febrero.

116. Ruibal, op. cit., p. 71

117. Suárez, op. cit., p. 419.

118. Suárez, op. cit., p. 913.

119. Naturalmente éstos no se representaban solamente en Navidad. 
de Vigo y Ferrol, la compañía Fantoches Españoles representó hasta en cinco ocasiones diferentes el melodrama bíblico El nacimiento del hijo de Dios, entre el 23 y el 28 de diciembre de 1885. Junto a esta obra, el público se divertía unos días con «diversos juegos y actuaciones de payasos y contorsionistas» ${ }^{120}$, otros con bailes españoles y franceses, sainetes, comedias, y aun otras piezas religiosas navideñas como La degollación de los inocentes, que habían escrito los ferrolanos Feliciano Pato y Francisco Piñeiro.

La comedia, el melodrama y la zarzuela religiosa cómica irán declinando su popularidad a lo largo del siglo XX. Sin embargo, quedan aquí y allá algunas obras navideñas que siguen representándose en los pueblos. La zarzuela Los pastores de Belén ${ }^{121}$, estrenada en Madrid por primera vez en 1914, aún se pone en escena en algunos lugares, como en Callosa de Segura, donde se estrenó en 1928. Y no son pocos los pueblos donde todavía sigue viva esta vis comica, recreada cada Navidad en diferentes formatos ritualteatrales, agrupados bajo la etiqueta de teatro popular ${ }^{122}$.

\section{Reflexiones finales}

En el siglo XIX el teatro se convierte en industria y pasa a depender de la demanda del público, algo que ya se vislumbraba en el Siglo de Oro -recuérdese a Lope: "porque, como las paga el vulgo, es justo hablarle en necio para darle gusto.» (vv.47-48) ${ }^{123}$-, pero que tiene su culminación en la época de la Restauración. Por otra parte, la variedad de públicos alentó salas de teatro y obras de diferente calado que cubrían las diferenciadas demandas, cuando no eran los propios aficionados quienes se lanzaban a emular las dotes de los actores profesionales. Unos y otros dieron respuesta a la demanda de diversión jocosa y escenificación sacra del misterio navideńo que constituía una auténtica tradición secular en pueblos y ciudades. Con las zarzuelas, comedias y diálogos burlescos que escenificaban el Nacimiento, la visita de los Reyes Magos o la huida a Egipto se cumplía por un lado con la lección moral obligatoria según la concepción que hasta finales del siglo pedía que el teatro fuera una «escuela de costumbres», y por otro lado satisfacía el deseo de comicidad, risa y diversión, propio de

120. E.C.G., n 2447, 23 de diciembre de 1885, p. 3.

121. Letra de Laureano Peña, música de Felipe Alcántara.

122. Véase Ch. Huet, «Panorama del teatro popular navideño en España», Culturas Populares. Revista Electrónica, 3, 2006.

123. Lope de Vega, Arte nuevo de hacer comedias, ed. de Enrique García Santo-Tomás, Madrid, Cátedra, p. 133. 
esas fechas. El teatro musical -la zarzuela, especialmente-, con su mezcla de costumbrismo, ingenuidad, escenografía espectacular, sin olvidar la música, se erigió en uno de los géneros propicios para la Navidad, en una época en que los escritores de zarzuelas eran los mismos que abastecían a los teatros populares con melodramas y dramones muy del gusto del pueblo. En esa producción masiva para consumo hay que encuadrar el teatro sacro navideño de finales del siglo XIX, sin olvidar que muchos de sus autores -así Adelaida Muñiz y Mas, por ejemplo- lo mismo escribían dramas sacros navideños que sainetes satíricos.

Lo que sorprende de ese teatro sacro no es tanto que en la segunda mitad del siglo XIX aún gozaran de popularidad los tópicos y escenas derivados del antiguo Officium Pastorum y el Ordo Rachelis, con la llegada de José y María a Belén, hasta la Adoración de los pastores y los Reyes Magos, sino que se representaran con similares recursos jocoserios que fueron santo y seña del drama navideńo desde las primeras obras de Juan del Encina, Gil Vicente, Lucas Fernández o Diego Sánchez de Badajoz. Naturalmente no son un calco de aquellas. La religiosidad y en general la cultura de la risa en el XIX, con sus vaivenes de estricta moralidad y reformismo, es bien distinta a la ambivalencia que impregnaba el drama religioso en los siglos XV a XVII. He puesto aquí de manifiesto la pérdida de ambigüedad y complejidad satírica, junto con el deslizamiento a un teatro un tanto naïf y peregrino, apto para todos los públicos: niños, religiosos, obreros o burgueses. Por otra parte las distancias no solo están en el género. De más está decir que como literato, José Felis no es Juan del Encina ni Lucas Fernández, aunque todos estuvieran vinculados a la Iglesia y a la música. Y sin embargo hay claros continuismos. Se ha aceptado tradicionalmente la progresiva desaparición del pastor bobo en el teatro del siglo XVII y XVIII, y su sustitución por otros personajes cómicos más complejos, como el gracioso de comedia. Los ejemplos aquí estudiados demuestran que en el siglo XIX aun perduraron, acaso recuperándose, algunos de los elementos jocosos más clásicos de nuestro teatro; no solo el pastor bobo, sino también las palizas a los malvados, el habla rústica, las porfías -verbales y en forma de agresiones- en las que llovían palos a los personajes escarnecidos, o el diablo, trivializado pero con un relevante papel en esa pedagogía cómica de larga tradición eclesiástica.

La comparación con otras formas rituales o parateatrales navideñas, desde las pastoradas a los diálogos escenificados de los aguilanderos, permite hablar de una tradición dramática común, basada en una religiosidad jocoseria, que si dio sus mejores frutos en el Renacimiento y el Barroco, siguió despertando interés en el siglo XIX. Es la pervivencia de una particular temposensitividad saturnalicia en las Pascuas, la que explica 
en gran medida la continuidad de esta tradición burlesca, más allá de los géneros literarios que gustaban en una época o en otra. Al fin y al cabo -como misterio- la Navidad ha tenido siempre vocación de inmutabilidad. Acaso por ello los dramaturgos religiosos de los últimos cinco siglos hayan aceptado una fórmula dramática que -año tras año- el pueblo esperaba ver representado, del mismo modo que gustaba -y gusta- repetir cada Navidad las mismas prácticas y usos en esa rueda del eterno retorno, a la que aún, pese a todo, estamos sujetos. 